\title{
Sofça Örnekleminde Kalburcu Şeyhi Pîr Ahmed Efendi ve Alevilik Anlayışı
}

\author{
Rifat Türkel*
}

Öz: Pîr Ahmed Efendi, XVI. yüzyılda Kütahya'da yaşamış, neslinden Müftî Derviş, Sunullâh-ı Gaybî gibi âlimler yetişmiş önemli bir zattır. Halvetî gelenekten gelen Pir Ahmed Efendi, yaşadığı dönemde muteber bir şahsiyettir. Onun bu itibarı, çeşitli kesimler arasında günümüze kadar var olmuştur. Ancak o XX. yüzyılın ikinci yarısından itibaren, özellikle bölgede yaşayan Aleviler tarafından sahiplenilmiş, bu durum günümüze kadar devam etmiştir. Mezarının bulunduğu Sofça'da ve civardaki Alevî köylerinde halen kendisine hürmet edilmektedir. Ayrıca Pîr Ahmed Efendi adına bir ocak ve bu ocağa bağlı tâlipler bulunmaktadır. Bu sebeple bu çalışmada ilk önce Pîr Ahmed Efendi'yi tanıtmayı, ardından gerek Pîr Ahmed Ocağındaki gerek Sofça köyündeki Alevîlik anlayışını tespit etmeyi amaçladık. Sofça'da ve Pîr Ahmed Ocağında Alevilik anlayışııın daha iyi anlaşılabilmesi için ilk önce Pîr Ahmed Efendi'nin hayatı ile ilgili yazılı kaynaklardan yararlanarak bilgi verdik. Daha sonra günümüz Sofça'sındaki Pîr Ahmed Efendi algısından bahsettik. Akabinde Sofçalı Alevilerin bağlı olduğu Koçulu Ocağı, Seyyid Kemal Sultan Ocağı ile Pîr Ahmed Efendi'nin adını taşıyan ocağın Alevilik anlayışını temel inanç ve ibadet esasları noktasından tespit etmeye çalıştık. Gerektiği yerlerde geleneksel Alevilik anlayışıyla karşılaştırmalarda bulunduk. Tüm bunları yapabilmek için nicel araştırma yerine nitel araştırmayı kullandık. Ön hazırlık olarak çalışma öncesi ilgili ocakların dedeleri ve Sofçalı tâliplerle Eskişehir, Kütahya ve Sofça'da mülâkat gerçekleştirdik.

Anahtar kelimeler: Pîr Ahmed Efendi Ocağı, Koçulu Ocağı, Seyyid Kemal Sultan Ocağı, Sunullâh-ı Gaybî, Alevilik, Cem, Ocak.

\begin{abstract}
Pir Ahmed Efendi is an important person who lived in Kütahya at XVI. century and arrived scholars from line of his family as Müfti Dervis, Sunullâh-ı Gaybi. Pir Ahmed Efendi who had been respected at his period, has been recalled to the present day by varied sections. However, he has been appropriated by Alevi's from begining from second part of XX. century, up to the present. He is still honoured between Alevi's at the state and in Sofca in which his grave is located in. Besides, there still is a household under his name and students in it. That's why in this work we aimed to present Pir Ahmed Efendi, and to determine Alevi perception in Sofca. We gave some information first about Pir Ahmed Efendi's life by using writing sources in order to make Alevi perception more clear in Sofca and Pir Ahmed household. Then, we have mentioned about understanding of Pir Ahmed Efendi in todays Sofca. Subsequently we tried to determine Alevi understanding of "Koculu Household" which is Alevi's of Sofca are connected, Seyyid Kemal Sultan Household and the House that bear the name Pir Ahmed Efendi from the point of basic belief and worshipping. We compared it to the traditional Alevi understanding in places. To do all of these we used quantitative researches instead of qualitative researches. And for provision we made an interview to mentors of mentioned households and students in Eskisehir, Kutahya and Sofca.
\end{abstract}

Keywords: Association of Pir Ahmed Efendi, Association of Koculu, Association of Seyyid Kemal Sultan, Sunullah-ı Gaybi, Alevism, Cem, Association.

* Yrd. Doç. Dr., Dumlupınar Üniversitesi, Illahiyat Fakültesi, İslam Mezhepleri Tarihi Anabilim Dalı. E-posta: rifatturkel@gmail.com. Adres: Evliya Çelebi Yerleşkesi Kamu Yönetimi Binası Tavşanlı Yolu 10. km/ Kütahya.

D0l: dx.doi.org/10.12658/human.society.6.11.M0177

İnsan ve Toplum, 6 (1), 2016 


\section{Giriş}

Sunullâh-ı Gaybî (ö.1676'dan sonra), 17. yüzyılda yaşamış Türk tasavvuf edebiyatının ileri gelen isimlerindendir. Gaybî'nin babası, "Müftî Derviş" lakabıyla meşhur Çavdaroğlu Ahmed b. Beşir b. Ahmed (ö. 17. yüzyılın sonları) olup Kütahya müftülüğü yaptığı için “Müftî Derviş" olarak tanınmıştır (Kurnaz, 1999). Dedesi Beşir b. Ahmed, büyük dedesi ise Kalburcu Şeyhi Pîr Ahmed Efendi'dir. ${ }^{1}$

Gaybî'nin büyük dedesi Kalburcu Şeyhi Pîr Ahmed Efendi günümüzde birçok topluluk tarafından hürmet edilen, adına etkinlikler düzenlenen bir kişidir. Aleviler onun adına 2009 yılından beri "Ulusal Pîr Ahmet Efendi Anma ve Kültür Festivali" düzenlemekte, bu etkinlikler çerçevesinde yemek pişirip dağıtmakta, semah gösterileri sunmaktadır. Diğer taraftan Kalburcu Şeyhi Pîr Ahmed Efendi, Halvetîlerin nazarında da saygı duyulan bir kişiliktir. Kendisinden sonra gelen aile efradının Halvetîliğe mensup olması ve bunların içerisinde Halvetî halifesi olmuş zatların varlığı dikkati çeker. Bu sebeple Pîr Ahmed Efendi'nin hem Halvetîler hem de Aleviler tarafından itibar edilen bir kişi olması araştırılması gereken bir durumdur. Zahidiyye tarikatı İbrahim Zahid Geylani'den (ö.1305) sonra Şeyh Safiyyüddin Erdebîli ile Safeviyye, Şeyh Ahi Muhammed Harezmî(ö.1378) ile de Halvetiyye olarak devam etmiştir. Neticede her iki tarikat aynı köklere dayanmakta, her ikisi de Sünni özellikler taşımaktadır. Ancak Safevî tarikatı, Şeyh Cüneyd (ö. 1460) zamanında siyasî bir hüviyete bürünmüş ve Şiiliği benimsemiştir.

Diğer taraftan Halvetîlik, ortaya çıktığı Horasan bölgesinin özelliklerini de taşımaktadır. Bu bölgede Ehl-i beyt önemli bir yere sahiptir. Bu sebeple Halvetîlik'te Ehl-i beyt motifinin önem arz etmesi doğal bir durum olarak telakki edilebilir. Aynı kökenden gelmeleri ve Ehl-i beyt motifinin ön plana çıkması Halvetî gelenekten gelen Pir Ahmed Efendi ve ahfadının Sofçalı Aleviler tarafından hürmet edilmesinde önemli bir etken olarak görülebilir.

Yine XVI. yüzyıldan itibaren Osmanlı Devletinin toprakları içerisindeki Türkmenleri kendi tarafına çekmek isteyen Şah İsmail ve Safevî Devleti'ne karşı, Ehl-i beyt sevgisi gibi Türkmenlerin sosyo-kültürel yapısına uygun motifleri taşıyan Halvetiliği desteklediği görülmektedir. Bunun sonucu olarak gerektiğinde Halvetî şeyhleri bir dede görünümünde Türkmenlerin arasında bulunmaktadır. Pîr Ahmed Efendi de Türkmenlerin arasında bir Alevi Dedesi gibi davranmış, Alevilerin hürmet ettiği bir dede konumuna gelmiş olabilir.²

Pîr Ahmed Efendi hakkındaki literatür incelendiğinde yazılı kaynaklardaki bilgilerin çok az ve birbirini tekrar eder mahiyette olduğu müşahede edilmektedir. Buradaki bilgilerin bir kısmı sözlü kültürdeki rivayetlerle desteklenirken, sözlü kültürde farklı rivayetler de görülmektedir. Bu sebeple Kalburcu Şeyhi Pîr Ahmed Efendi hakkında ulaşılabilen yazılı ve sözlü kaynaklar çerçevesinde bilgiler verilecektir. Diğer taraftan kabrinin bulunduğu günümüz Sofça halkının Pîr Ahmed Efendi ve Alevilik anlayışıyla ilgili literatürde bilimsel bir çalışma

1 Ailenin soy kütüğü İsmail Hakkı Uzunçarşııı tarafından verilmiştir. Bkz. Uzunçarşılı 1932. Gaybî'nin hayatı, eserleri ve şiirleriyle doktora çalışması bulunan Bilal Kemikli, Uzunçarşılı́nın verdiği soy kütüğünün kısmen doğru olduğunu ifade etmektedir (Kemikli 2000).

2 Mustafa Aşkar "Bir Türk Tarikatı Olarak Halvetiyye'nin Tarihi Gelişimi ve Halvetiyye Silsilesinin Tahlili"; Hulusi Yılmaz da "Halvetilik ve Anadolu Aleviliği İlişkisi Çerçevesinde Pir Ahmet Efendi Ahfadına Genel Bir Bakış" isimli makalesinde Halvetîlik-Alevilik, Alevîlik-Pîr Ahmed Efendi ilişkisi hakkında değerlendirmelerde bulunmaktadır. Ayrıntılı ilgi için bkz. (Aşkar 1999), (Yılmaz 2013). 
dikkati çekmemektedir. Bunun bir neticesi olarak Sofçalıların Pir Ahmed Efendi'yi tanımlama şekli ve Alevilik anlayışı tespit edilmeye çalışılacaktır.

Bu çerçevede Pir Ahmed Efendi'nin geçmişteki ve günümüzdeki algılanışı yazılı kaynaklar ve sözlü kültüre dayalı olarak ele alınacaktır. Yine Sofça'daki Alevilerin din anlayışını tespit etmek için nitel araştırma yöntemleri kullanılmıştır. Buna bağlı olarak geleneksel Alevilikle ilgili yazılı eserler, alan araştırması için nitel araştırma yöntemi olan görüşme tekniği kullanılmıştır. Bu çerçevede Sofçalı Alevîlerin bağlı olduğu ocak dedeleri ve Sofçalılarla görüşmeler etrafında kaynak kişiler kullanıımıştır. Görüşme yapılan kişilerin yazı sonunda ayrıntılı olarak verilmiştir. Görüşmeler "Görüşme formunun" içeriğine uygun olarak gerçekleştirilmiştir. Böylece Pîr Ahmed'in kabrinin bulunduğu Sofça Köyü halkının Alevilik anlayışı, Sofça Alevilerinin kendilerini tanımlama şekli Sofça'daki tâliplerin bağlı olduğu ocak dedeleri ve Sofçalı tâliplerle yapılan görüşmeler çerçevesinde ortaya konulmaya çalışılmıştır.

\section{Kalburcu Şeyhi Pîr Ahmed Efendi}

Kalburcu Şeyhi Pîr Ahmed Efendi (ö.1570) hayatı hakkında kaynaklarda sınırlı bilgi bulunan ancak onunla ilgili rivayet ve menkıbelerin çok olduğu bir kişidir. Kütahya'nın Kalburcu köyünden olması sebebiyle isminin önünde "Kalburcu" ifadesi zikredilmiştir. Diğer taraftan O, "Pîr", olarak da isimlendirilmiştir. Pîr, tasavvufta bir tarikatın kurucusu, sâlike rehberlik yapan kimse anlamına gelmekle birlikte Pîr Ahmed Efendi, herhangi bir tarikatın kurucusu değildir. Bu nedenle onun Pîr olarak anılmasının farklı muhtemel sebepleri olması gereklidir. Gaybî üzerine çalışmaları bulunan Bilal Kemikli, Pîr sıfatının onun için "sohbet şeyhi" anlamında kullanıldığını ifade ettikten sonra Gaybî'nin büyük dedesi ile ilgili "Cedd-i âlâmı Kalburcu Şeyhi Pîr Efendi hazretlerini Cafer Paşa ziyarete gelmiş: "Sultanım dervişin çok mu?" demiş. "Gelür gider çok beğim." demiş, "dervişim var" dememiş." (Gaybî) ifadelerinin bunu desteklediğini, dolayısıyla Gaybî'nin büyük dedesinin, herkesin sohbetine katıldığı, sözlerini dinlediği, hal ve hareketlerini örnek aldığı bir kimse olduğunu, bu sebepten kendisine "Pîr" denildiğini söyler. Gaybî'nin sözlerinden asker ve devlet adamlarının da onun sohbetlerine katıldığı anlaşılmaktadır (Kemikli, 2000). Mustafa Tatcı ve Cemal Kurnaz da onun Pîr olarak adlandııımasının yaşııı̆ı̆ıda hilafete getirilmesiyle alakalı olduğu kanaatindedir (Kurnaz, 1999).

Bazı kaynaklarda Kalburcu Şeyhi'nden bahsedilirken "Çavdarlı Şeyh" (Çelebi, 1935) veya "Çavdar Şeyh" ifadeleri de kullanılmaktadır. Ancak bu ifadelerin gerek lakap gerek mahlas olarak kul Pîr Ahmed Efendi için kullanıldığını söylemek mümkün görünmemektedir. Çünkü bu ifadeler lakap olarak oğlu Beşir Efendi için kullanılırken Gaybî'nin babası Kütahya Müftüsü Müftî Derviş şiirlerinde bu ifadeyi mahlas olarak kullanmıştır (Kurnaz, 1999). ${ }^{3}$ Taşköprizâde, Pîr Ahmed Efendi'nin çavdar lakabının yanında mihmandar (misafirperver) lakabına da sahip olduğunu ve kendisine "Çavdar Şeyhi" denilme sebebinin normal buğday ve çavdar tohumları ekmesine rağmen hasat döneminde benzersiz buğdaylar elde etmesi olduğunu ifade eder (Atâî, 1269).

Kalburcu Şeyhi Pîr Ahmed hem Karamanlı Cem Seyyah'tan hem de Şeyh Sümbül Sinan'dan hilafet almıştır. Gaybî'nin Biatnâme isimli eserindeki: 
“Cedd-i âlâmız Kalburcu Şeyhi Pîr Ahmed Efendi Hazretleri Karaman'da Cem Seyyah'a ve İstanbul'da Koca Mustafa Paşa Şeyhi Sünbül Sinan'a nice müddet kemâl-i mertebe hizmetler eyleyüp tarikleri muktezâsınca hilâfete icâzet buyurduklarından sonra hâle muvâfık ve istimdâdıma lâyık insan-ı kâmil sohbetine vâsıl olmadım diyû tehassürleri menâkıblarında mezkûr ve beyne'l-ahbâb meşhurdur." (Gaybî)

sözlerinde ifade edilmektedir. ${ }^{4}$ Mahmûd Cemâleddîn Hulvî de onun İstanbul'da Mustafa Paşa Zaviyesi'ndeki Şeyh'e biat ettiğini daha sonra hilafet vazifesiyle görevlendirilip Anadolu'ya gönderildiğini söyler (el-Hulvî, 1993). Bunun yanında bazı kaynaklar onun Merkez Muslihuddin Efendi'den (ö.959/1552) hilafet aldığını, Halvetiyye-Şâbâniyye tarikatının kurucusu Şâbân-ı Veli'den (ö.976/1569) istifade ettiği belirtilir.5 Ancak her iki durum arasında tenakuz bulunmaktadır. Çünkü Merkez Efendi, Sünbül Sinan'ın postnişinidir. Pîr Ahmed, Sünbül Sinan'dan hilafete icazet aldığına göre Merkez Efendi zamanında ikinci kez hilafet icazeti alması söz konusudur ki bu bir çatışmadır. Bilal Kemikli de onun Merkez Muslihiddin Efendi ve Şâbân-ı Veli ile alakasına yönelik iddiaların ilmî gerçeklikten uzak olduğu kanaatindedir (Kemikli, 2000).

Pîr Ahmed Efendi, İstanbul'da icazet almasının ardından köyüne geri dönmüş, zaviyesine gelip gidenlerle burada bulunanlara ikramlarda bulunmuştur. Geçimini çiftçilikle sağlamış, hayatı boyunca bağış, sadaka, hediye ve yardım kabul etmemiştir. Elde edilen buğdaydan misafirler için ekmek yapmayı ve hayvanlara yiyecek olarak arpa ayırmayı adet edinmişlerdir. Onun kerametlerinden bahseden rivayetlerde zaviyedekilerin elde edilen buğdayları bir ambara koyarak ağzını kapattığı, çavdarı ambarın altındaki oluktan aldıkları, ambarın boş kaldığına ve ihtiyaçlarının sınırlandığına şahit olunmadığı, ziyarete gelenlere ayrılırken yol azığı olarak birer çörek verildiği, Pîr Ahmed Efendi'nin bu bolluğu ifade sadedinde "Bu bereket, Şeyhim Abdullatif Efendi'nin bereket duasıdır." deyip teşekkür ettiği söylenir (Atâî, 1269; Uzunçarşılı, 1932).

Kaynaklarda II. Selim'in şehzade iken Pîr Ahmed Efendi'yi ziyareti esnasında kendisinden dua ve himmet talep ettiği, zaviyesi yanında bir mescit inşa ettirdiği ve vefatının adından Pîr'in burada defnedildiği ifade edilir. 1573 senesinde vefat eden Pîr Ahmed Efendi'nin türbesini Evliya Çelebi ziyaret etmiştir. (Atâî, 1269; Çelebi, 1935; Kurnaz, 1999) 1949 yılında bölgede yapılan Porsuk Barajı́nın yapımı esnasında sular altında kalmaması için türbe şimdiki yerine taşınmıştır (Kemikli, 2000). ${ }^{6}$

4 Taşköprizâde, Kalburcu Şeyhi Pîr Ahmed Efendi'yi "Ahmed Dede" başlığı altında ele almış, burada onunla ilgili “Şehrinin âlimlerinden fenleri, Cem Seyyah'tan farz ve sünnetlerin manalarını öğrendiğini, Şeyh Sinan Karamânî'nin hizmetine vasıl olduğunu, Abdullatif Efendi'nin de nazarı kerâmetine nail olduğunu ifade etmektedir." (Atâî 1269).

5 Taşköprizâde, Cem Seyyah'tan, Şeyh Sinan Karamânî ve Abdüllatif Efendi ile olan münasebetinden bir müddet sonra İstanbul'a gelip, Merkez Efendi'nin yanında tekmili tarikat eylediği ve irşad için icazete nail olduğu sonradan Kastamonulu Şa'ban Efendi'nin yanında nazarı inayet ile ser-afrâz olduğunu söyler (Atâî 1269; Süreyya 1996; Uzunçarşılı 1932).

6 Pir Ahmed Efendi'nin kabri, Porsuk Barajı inşaatı sırasında sular altında kalmaması için daha yukarı, Kütahya-Eskişehir karayolunun soluna, dağın eteklerine aktarılarak bir türbe yapılmıştır. Bu aktarım işiyle, Gaybî'nin torunlarından Gaybî Bey ve Ahmet Yakuboğlu özellikle ilgilenmişlerdir. Mezar kazılıp naaş ortaya çıkınca Yakuboğlu, Pîr Ahmed Efendi'nin başından alçı bir portre almıştır. İzlenimlerine göre temsili resmini çizmiştir. Yakuboğlu, Pîr Ahmed Efendi'yi torunlarından arkadaşı da olan Hamdi Özeren'e (ö. 1374/1954) benzetmektedir. Bkz. Doğan, 2001. 


\section{Günümüz Aleviliğinde Pîr Ahmed Efendi}

Sofça sınırları içerisinde bulunan Pîr Ahmed Efendi Türbesi'nin 1949 yılındaki nakli sırasında nahiye olması sebebiyle Sabuncupınar'a taşınması gündeme gelmiş ancak dönemin başbakanının isteği üzerine Sofça sınırları içerisindeki yeni yerine taşınmıştır. Sofça halkının bir kısmı Porsuk Barajı́nın sular altında kalmayan bölümünde ikamet etmeye devam etmiş, bir kısmı da Eskişehir sınırları içerinde kurulan Yeni Sofça köyüne taşınmıştır. Sofçalı kaynak kişiler Pîr Ahmed Efendi'nin türbesinin uzun müddet bakımsız kaldığını ancak Sofçalıların gayretleriyle türbenin hem bakımının yapıldığını hem de civarda önemli bir konuma gelmesinin sağlandığı ifade eder. Sofçalıların Pîr Ahmed Efendi ve türbesine sahip çıkmalarının bir tezahürü olarak 2009 yılından itibaren onun adına festival düzenlenmekte kurbanlar kesilmekte, yemek ikram edilmektedir. Ayrıca bu tarihlerde cem törenleri tertip edilmekte, semah gösterisi sunulmaktadır. Etkinliklere farklı şehir ve köylerdeki Alevilerden katılım ve destek sağlanmaktadır.

Sofça köyü sınırları içerisinde bulunması dışında Pîr Ahmed Efendî'nin Sofça yakınlardaki bölgelerde ocak dedesi olarak kabul edilmesi ve Pîr Ahmed Ocağına bağlı tâliplerin olması Pîr Ahmed Efendi'yi gerek Sofçalıların gerek diğer Alevi tâliplerinin arasında saygı duyulan ve hürmet edilen bir dede olarak kabulüne sebep olmuş görünmektedir. Yine Pîr Ahmed Ocağı Dedesi Ali ve Oktay Garkın dedelerle yapılan görüşmelerde ocak şeceresinin Pîr Ahmed Efendi öncesi ve Pîr Ahmed Efendi sonrası olmak üzere iki bölümden oluştuğu görülür. Şecereden anlaşıldığına göre Pîr Ahmed Efendi Ocağı kendisini Dede Garkın Ocağı'nın devamı olarak ifade etmektedir. Buna göre Dede Garkın, kuvvetle muhtemel olarak Moğol istilası sebebiyle müritleriyle birlikte Anadolu'ya gelmiş, burada yerleşmiştir. Devrin Sultanı onun meziyetlerini görerek onunla dostluk kurmuş, neticede kendisine on yedi köyü vakıf olarak tahsis etmiştir. Vilâyetnâme'deki bilgilerden Dede'nin Elbistan'a yerleştiği tahmin edilmektedir. O burada yıllarca fikirlerini yaymıştır. Dört yüz kadar halifesinin olduğu rivayet edilir (Ocak, 1996). Ocağının, Anadolu'ya Horasan üzerinden gelen diğer oymaklarda olduğu gibi Yesevi Ocağının devamı olduğu ileri sürülmektedir. Diğer taraftan II. Mahmut'un fermanından anlaşıldığı üzere posta menzili görevinde bulundukları, bir başka belgede de ocak mensuplarının kömür üretme ve taşıma görevlerini de yerine getirdikleri görülür (Yılmaz, 2002). Pîr Ahmed Ocağı dedelerinden Oktay Garkın Dede, II. Mahmud (1808-1839) zamanında Bektâşî tekkelerinin kapatılmasının ardından Dede Garkın Ocağından Feyzullah Dede'nin idam edildiğini bu tarihten sonra korku ve endişe sebebiyle Dede Garkın Ocağının Pîr Ahmed Dede'nin ismiyle anılmaya başlandığını, Pir Ahmed Ocağı olarak isimlendirildiğini ifade eder.

Yine Alevilikteki evliya veya eren kültü önemli bir unsur olarak bulunmaktadır. Bunun sonucu olarak tasavvuf erbabındaki bazı kerametler boy, soy veya ocak evliyası için de söz konusudur. Abdal Musa Vilayetnâmesi'nde "Az yemekle çok insanın doyurulması" şeklinde tasavvur edilen keramet ${ }^{7}$ Sofça ve civarında Pîr Ahmed Efendi ile ilgili de tâliplerin çoğu tarafından dile getirilmektedir. Pîr Ahmed Efendi Ocağının dedeleri ve Sofçalı Alevilerle yapılan görüşmelerde Pîr Ahmed Efendi'den evliyadan keramet sahibi bir zat olarak bah-

7 Cenksu Üçer'e göre evliya veya eren kültü çerçevesinde boy veya aşiret evliyaları için menkıbelerin olması, bunların diğer bölge ve ocaklarla benzerlik göstermesi tasavvuf telakkilerini yaşamış oldukları gruba uyarlamalarının bir sonucudur (Üçer, 2010). 
sedilmektedir. Yine çoğu kişi tarafından onunla ilgili meşhur bir menkıbe anlatılır. Buna göre Pîr Ahmed Efendi'nin yaşadığı dönemde Porsuk, çay halinde akar. Osmanlı askerleri sefer esnasında Dede'nin mekânında konaklar. Burada pişirilen bir çömlek pilav tüm askere yeter. Yine Pîr Ahmed Efendi'nin kalburla su taşıdığı müşahede edilir. Bunu gören askerlerin komutanı Pîr'in keramet sahibi olduğuna kanaat getirir. Pîr'e "Dede biz karşıya geçeceğiz" deyince Pîr Ahmed Efendi, "Siz yatın. Sabah ola hayr ola, sabahın sahibi Allah" der. Askerler sabah kalktıklarında köprünün yapılmış olduğunu görür. Askerler sefere gittiklerini, ondan dua istediklerini ifade edince, o da sıkıntıya düştüklerinde, "Ya Allah, Ya Muhammed, Ya Ali, Yetiş Ya Pîr Ahmed diye meded dilediğinizde ben gelirim" der. Sefere çıkan askerler bu arada saldırıya uğrar. Dedenin söyledikleri aklında olan komutan onun tarif ettiği şekilde istimdatta bulunur. Bu arada bir toz bulutu kalkar, içinden bir tahta parçası komutanın önüne düşer. Seferden sonra komutanın önüne düşen tahta parçası yanlarında olduğu halde geri dönen askerler, Pîr Ahmed Efendi'nin yanına ulaştıklarında ona kendisini yardıma çağırdıklarını fakat kendisinin yardım etmediğini söylerler. Onlara yardım ettiğini ifade eden Pîr, askerden yanındaki tahta parçasını ister. Yanında bulunan yabanın eksik bölümüne parçayı yerleştirir. Bunu gören askerler onun keramet sahibi olduğuna bir daha şehadet eder. Bunun üzerine komutan ve bazı erler onun yanında kalmak istediklerini belirtir.

Daha önce ifade edildiği üzere Pîr Ahmed Efendi'ye hürmet gösteren ve onun adına etkinlikler düzenleyen Sofçalılar Alevi olarak tanınmaktadır. Yaptığımız alan araştırmasında Sofça halkının ocaklara bağlı Alevilik anlayışına sahip olduğu görülür. Sofçalılar her ne kadar Pîr Ahmed Efendi'ye saygı ve hürmet gösterseler de köyde Pîr Ahmed Ocağına bağlı tâliplerin bulunmadığı tespit edilmiştir. Pîr Ahmed Ocağına mensup tâliplerin Yeni Sofça, Kırgıl, Fındık gibi civar köylerde varlığı dikkati çeker. Sofça'da ise Koçu Baba ve Seyyid Kemal Ocakları olmak üzere iki ocağa bağlı tâlipler bulunmaktadır. Pîr Ahmed Ocağının yolunu Ali Garkın Dede'nin onay ve tensibiyle oğlu Ali Rıza Garkın Dede ve Oktay Garkın Dede halen yürütmektedir. Sofçalıların çoğunun mensup olduğu Ankara'daki Koçu Baba Ocağının dedesi Abidin Dede'nin vefatı üzerine kardeşinin oğlu Cafer Dede dedelik vazifesini üstlenir. Onun ölümünden sonra yerine geçmesi gereken oğlu Ahmet Koç'un görevi üstlenmeye hazır olmadığını beyan ederek dedelik yapmayı istememesi üzerine ocağın bağlı olduğu Hacı Bektaş Dergâhı'ndan Ali Rıza Ulusoy Dede tayin edilir.

Sofça'daki bir kısım Alevinin bağlı olduğu diğer ocak Seyyid Kemal (Cemal) Sultan Ocağında Mustafa (Demir) Dede ile Ali (Demir) Dede bulunmaktadır. Her iki dede Afyon'un Alanyurt köyünden olup Ocak tâlipleri ile yapılan mülakatlarda tâliplerin daha çok Mustafa Dede'nin cemlerine iştirak ettikleri, onun tarafından görüldükleri tespit edilmiştir.

Çalışmamızda Sofça ile ilgili bahsedilen ocakların ve tâliplerinin Alevilik anlayışı, İslam'ın inanç ve ibadet esasları ile ilgili tutum ve davranışları, âdâb ve erkânlarının tespiti önem arz etmektedir. Bu sebeple ocak dedeleri ve tâlipleriyle yapılan mülakat ve anket çalışmasından yola çıkarak bu konulardaki Sofça ve diğer şehirlerdeki Sofçalı tâliplerin Alevilik anlayışını ele alacağız. 


\section{İnançlar}

\section{Hak-Muhammed-Ali}

Aleviliğin inanç anlamında en önemli sembollerinden birisi Allah-Muhammed-Ali ya da HakMuhammed-Ali şeklinde ifade edilen kavramdır. Uluhiyet-nübüvvet-velayet mertebelerinin sembolize edilmesi şeklinde bu kavramın ana unsuru Allah, Hakk'tır. Bu anlayış Aleviliğin kültürel ve dinî değerlerinin etkisiyle zaman içerisinde şekillenmiştir. Geleneksel Alevilik'te Allah âlemi yaratan tek varlık olarak ele alınır. Bu sebeple İslam'daki ilah tasavvuru dikkate alınmış, Buyruk'ta Allah her şeyi yaratan, bilen, işiten, mükâfat veren bir varlık olarak tarif edilmiştir (Buyruk, 2012). Bu anlayıştaki dikkati çeken husus tasavvuftaki vahdet-i vücûd anlayışının Alevilikte de var olmasıdır. Pîr Ahmed Ocağında bu anlayış “Hakk'ta hak olmak, Hakk'ta yok olmak" şeklinde ifadesini bulmuştur. Buna göre insan ve diğer varlıklar O'ndan bir parçadır.

Sofçalı Alevilerin bağlı olduğu ocak dedeleri ile yapılan mülakatlarda onların geleneksel Alevilikteki ilah anlayışına sahip oldukları müşahede edilmektedir. Bu konuda kendilerine sorulan sorulara İhlâs Suresi'nin anlamı ile cevap vererek Allah'ın bir olduğunu, eşi ve benzeri bulunmadığını, hiçbir şeye muhtaç olmadığını, doğmadığını ve doğurmadığını ifade ederler. Dedelerin ifadesiyle âlemde gerçek varlık Allah'tır. Bu sebeple âlemdeki her şeyin onun tecellisi ve zuhuru olduğu ile ilgili vahdet-i vücûd düşüncesi tâliplerin arasında tartışma ve sohbet konusu değildir. Bu tür tartışmalar Alevi önder ve dedelerinin arasında cereyan eder. Dedelerin ifade ettiği bu konu Sofçalı tâlipler arasında da müşahede edilmiştir. Onlara göre Allah bir, yaratıcı, eşi ve benzeri olmayan bir varlıktır. Bunun dışında tâlipler O'nun ile ilgili tasavvufi yorumlardan bahsetmez.

Alevilikteki Allah-Muhammed-Ali üçlemesinin diğer önemli bir unsuru Hz. Muhammed'dir. Geleneksel Alevilikte Hz. Muhammed'in Allah'ın resulü olduğuna dair bilgiler mevcut olsa da daha çok onun miraca çıkması, Ali'nin sırrına ermesi, Ali ile aynı nurdan olmaları, Ali'ye el vermesi gibi hususlardan belirgin olarak bahsedilir (Buyruk, 2012). Ancak burada $\mathrm{Hz}$. Muhammed'in İslam'daki yeri ve öneminin gerektiği şekilde anlaşılmadığı, onun "hakikat-i Muhammedî" kavramı etrafında değerlendirildiği görülmektedir (Üzüm, 2013).

Aleviliğin kültürel kaynaklarında Hz. Muhammed daha çok Hz. Ali ile birlikte anılmış, özdeşleştirilmiş bu durum Muhammed-Ali ifadesiyle simgeleştirilmiştir. ${ }^{8}$ Sofçalı Alevilerin bağlı olduğu ocak dedeleri İmam Cafer Buyruğundaki anlayışa uygun olarak âlem yaratılmadan önce Muhammed ile Ali'nin nurunun var ve bir olduğunu, daha sonra bu nurun Abdülmuttalib'in çocukları Abdullah ve Ebû Tâlip'te ayrıldığını, Hz. Muhammed'in nurunun Abdullah'tan, Hz. Ali'nin nurunun ise Ebû Tâlip'ten geldiğini ifade eder (Buyruk, 2012). Hz. Muhammed'den sonra imametin Hz. Ebû Bekir'in değil, Hz. Ali'nin hakkı olduğu iddiasını bu düşünce ile temellendirir. Çünkü Muhammed ve Ali aynı nurdan olup Muhammed-Ali şeklinde ifade edilmiştir. ${ }^{9}$

Doğan Kaplan Alevî kaynaklarındaki Muhammed-Ali kullanımının yolun kurucusu olarak bu iki zatın birbirlerinden ayrılmazlığını, aralarındaki muhabbet ve ülfeti göstermeye yönelik olabileceğini söyler. Bazı örneklerle bu kullanımın Alevîlik yolunun meşruiyetini ve diğer yollara karşı üstünlüğü çağrıştırdığını ifade eder (Kaplan, 2011a).

9 Oktay Garkın Dede'nin ifadeleriyle bu tür konular tâlipler arasında değil, daha çok dedeler arasında konuşulur. 
Pîr Ahmed ve Seyyid Kemal Sultan ocaklarının dedeleri Muhammed-Ali tasavvurunu şu olayla desteklerler: “Hz. Peygamber'e veda haccı sonrası dönüş yolunda "Ey Peygamber! Rabbinden sana indirileni tebliğ et. Eğer bunu yapmazsan, O'nun verdiği peygamberlik görevini yerine getirmemiş olursun. Allah, seni insanlardan korur. Şüphesiz Allah, kâfirler topluluğunu hidayete erdirmeyecektir." (Maide, 5/67) ayeti gelir. Bunun üzerine bir minber hazırlatan Hz. Peygamber, Hz. Ali'nin elinden tutarak "Ben kimin efendisi isem Ali de onun efendisidir." buyurarak Hz. Ali'ye "Ya Ali Ben ilmin şehriyim, sen de kapısısın" der. Böylece onu kendisine kardeş kılar. Bu arada Cebrâil'in cennetten getirdiği gömleği giyen $\mathrm{Hz}$. Ali'ye hitaben Hz. Peygamber: "Lahmuke lahmî, cismuke cismî, demuke demî, rûhuke rûhî. / Etin etim, bedenin bedenim, kanın kanım, ruhun ruhumdur." ifadelerini kullanır (Kaplan, 2011a, 2011b).

Dedeler, Hz. Ali'yi geleneksel Alevilikteki gibi vasi olarak da telakki ederler. Hz. Ali'nin $\mathrm{Hz}$. Peygamber'in vasisi ve $\mathrm{Hz}$. Muhammed'in vefatından sonra imametin $\mathrm{Hz}$. Ali'nin hakkı olduğunu Gadîr-i Hum olayını naklederek değerlendiren dedelere göre Hz. Muhammed, veda haccı (632) sonrası dönüşte Gadîr-i Hum denen mevkide konaklar. Bu esnada Mâide suresinin 67. ayeti nazil olur. Öğle namazının ardından ashabına bir konuşma yapan $\mathrm{Hz}$. Peygamber, konuşmasında vefatının yaklaştığına işaret ederek dünyada iken risâlet görevini yapıp yapmadığına dair ashabından şehadet almış, sonra "sekaleyn hadisi" olarak meşhur olan "Size paha biçilmez iki şey bırakıyorum: Allah'ın kitabını ve Ehl-i beytimi... Benden sonra bunlara sarılırsanız asla sapıklığa düşmezsiniz" şeklinde hitap etmiştir. Hz. Peygamber bu konuşmadan sonra $\mathrm{Hz}$. Ali'yi sağ tarafına alarak elini tutup kaldırmış ve "Ben kimin mevlâsı isem Ali de onun mevlâsıdır. Allah'ım onu seveni sev, ona düşman olana düşman ol!" diyerek dua etmiştir. Arkasından içerisinde Hz. Ebû Bekir ve Hz. Ömer'in de bulunduğu sahabeler Hz. Ali'yi tebrik etmiştir.

Sofça, Kütahya ve Eskişehir'de bulunan tâlipler arasında Allah-Muhammed-Ali kavramı ile ilgili olarak geleneksel Alevilikteki anlayışın hâkim olduğu görülür. Onlar Allah'ın varlığı ve birliği konusunda tereddütsüz olumlu cevap vermişlerdir. Onlara göre Allah vardır, birdir ve âlemi yaratandır. Hatta Sofça'daki tüm Aleviler, Alevilerin bazıları tarafından kabul gören Allah'ın yok olduğu düşüncesini reddeder. Bazıları da bu durumu sapıklık olarak niteler.

Hz. Muhammed ile ilgili ise onun Allah'ın Peygamber'i olduğu, kendisinden sonra peygamber gelmeyeceği düşüncesi hâkimdir. Tâliplere Lahmuke lahmî ve Muhammed-Ali'nin aynı nurdan olması ile ilgili sorular sorduğumuzda bilgilerinin yüzeysel olduğu hatta bazılarının bu konuda hiç bilgi sahibi olmadıkları görülmüştür. Bu durum dedelerle görüşmemizdeki onların "bu tür konuları tâliplerle değil kendi aralarında konuştuklarına dair" ifadeleriyle örtüşmektedir. Yine onlara göre Hz. Muhammed ve Hz. Ali aynı nurdan olma iki ayrı kişiliktir. Hz. Muhammed nebi iken $\mathrm{Hz}$. Ali velayet makamındaki veli, velilerin şahıdır. Bu sebeple Hz. Ali'yi ilah telakkisi görülmemektedir. Bu tür iddialar bazı dedeler ve tâlipler tarafından sapıklık olarak nitelendirilmektedir. 


\section{Diğer Inançlar}

Meleklere Iman

Sofça Alevilerinin Allah-Muhammed-Ali inancı dışındaki melek, peygamber, kutsal kitap, ahiret ve kaza kader inançlarını da ele almak gereklidir. Pîr Ahmed Ocağı dedelerinin meleklerin yaratılışı ile ilgili anlattığı bir olay onların melek anlayışlarını bilmek için önemlidir. Buna göre Allah âlemi ve insanları yaratmadan önce ilk olarak meleklerin ruhlarını yaratır ve meleklere "Siz kimsiniz, ben kimim?" diye sorar. Bu soru üzerine meleklerin ruhları "Sen sensin, biz de biziz." derler. Bu cevaptan hoşnut olmayan Allah onların ruhlarını ortadan kaldırır. Daha sonra Cebrâil'in ruhunu yaratan Allah, ona da "Sen kimsin, ben kimim?" diye sorar. Daha önce meleklerin ruhlarının başına gelen olaydan haberi olduğu için Cebrâil, "Ey Rabbim, bana biraz müddet tanırsan bu sorunun cevabını öğreneyim." diyerek müsaade ister. Allah tarafından kendisine verilen izin üzerine bir rivayete göre arş-ı âlâda kırk bin sene bu sorunun cevabını arayan Cebrâil orada bir nur görür. Nura yaklaşınca onun bir kandile benzediğini fark eder. Nurun içinden kendisine: "Ey Cebrâil, Cenâb-ı Allah sana bir soru sordu. Ona "Sen yaratansın, ben yaratılanım" diyerek cevap ver, bu Allah'ın hoşuna gider" şeklinde bir ses gelir. Cebrâil Allah'ın huzuruna gidip bu cevabı verdiğinde Allah ona "Ya Cebrâil, bu cevap senin değil, nereden öğrendin?" diye sorarak "o gördüğün kandildeki nuru henüz yaratmadım. Kâinatı onların yüzü suyu hürmetine yaratacağım." ifadelerini kullanır. O kandildeki nur Hz. Peygamber ve Hz. Ali'nin nurudur.

Ali Garkın Dede, mülakatta meleklerin Allah'a karşı devamlı ibadet halinde, nurdan görünme varlıklar olduğunu söyler. Seyyid Kemal Sultan Dedesi Mustafa Dede tarafından bu husus zikredilmez. Ancak tüm dedeler Cebrâil, Azrâil, Mikâil, İsrâfil'in vazifeli melekler olduğunu kabul ederler. Sofçalı Aleviler de meleklerin nurdan yaratılmış, yeme-içmesi olmayan varlıklar olduğunu ifade ederler. Melek inancı konusunda halk daha çok sathi boyutlarıyla meseleyi ele almakta onların yaratılma süreci ve şekli ile ilgili mitolojik anlatımlarla ilgilenmemektedir.

\section{Kitaplara Iman}

Kültürel ve geleneksel Alevi kaynaklarında kitaplara inanmanın gerekliliğini içeren bilgiler mevcuttur. Ana kaynak İmam Cafer Buyruğu'nda insanların doğuştan bilgi sahibi olmadığı, bu sebeple Hak Teâlâ'nın kullarına İblis'in yolunu ve doğru yolu bildirmek için kitaplar gönderdiği ifade edilir. Hz. Ali'den rivayet edildiğine göre Allah sırlarının hepsini dört kitapta (Tevrat, Zebur, İncil, Kur'an-ı Kerim) bildirmiştir. Bu dört kitaptaki esrarını Fatiha suresi, Fatiha suresindeki esrarının hepsini besmelenin içerisine koymuştur. Besmeledeki esrarının tamamını ise Yasin suresinde gizlemiştir. Yâsin suresindeki sırlarının tamamını da "ب/ba harfindeki noktada gizlemiştir (Buyruk: Imam Cafer-i Sadık Buyruğu, 2013). Kültürel kaynaklarda dört kitaba inançları olduğu görülen Alevilerin bu anlayışı, Pîr Ahmed Efendi, Koçulu ve Seyyid Kemal Sultan ocaklarının dede ve tâlipleriyle yapılan mülakatlarda da görülür. Aynı zamanda Ali Garkın Dede bazı peygamberlere suhuf gönderildiğini belirtmiş, suhufların sayfa sayısı hakkında bilgiler vermiştir. Ancak bu sayfa sayılarının İslam'daki suhufların sayfa sayısı ile farklılık gösterdiği görülür. Sofçalı tâlipler de dört kitaba olan inançlarını dile getirmiş, kitaplar ve suhuflar hakkında ayrıntılı bilgi verememişlerdir.

Gerek dedeler gerekse tâlipler boyutuyla kitaplara inanan Sofçalılar Kur'an-ı Kerim anlayışları yönüyle farklılık göstermektedirler. Bu farkılık ilk etapta dedeler boyutuyla kendisini 
göstermektedir. Pîr Ahmed Ocağından Ali Garkın Dede, Kur'an'ın günümüze kadar orijinalliğinin bozulmadan eksiksiz olarak gelemediğini dile getirir. Ancak ona göre elde bulunan mevcut Kur'an bu haliyle bile yeterlidir. Seyyid Kemal Ocağından Mustafa Dede ise Kur'an'ın tahrifinin ve eksikliğinin söz konusu olamayacağını belirterek bunu Kur'an'ın "Şüphe yok ki Kur'an'ı biz indirdik ve şüphe yok ki onu mutlaka koruyacağız." (Hicr, 15/9) ayetiyle temellendirir. Ayet sayısından yola çıkarak Kur'an'ın tahrif edildiğini veya eksik olduğunu iddia etmenin doğru olmayacağını belirtir. Ona göre Kur'an'ın noktası dahi değişmemiştir. Sofça'daki Seyyid Kemal Sultan Ocağı tâliplerinin bu konuda ocağın dedesiyle aynı düşüncede oldukları müşahede edilmektedir. Koçulu ocağı tâlipleri ise bu konuda homojen bir görüntü vermez. Çünkü çoğunluğu Kur'an'ın eksik olmadığını veya tahrif edilmediğini beyan etmiş olsa da bir kısmı Kur'an'ın eksik olarak günümüze kadar geldiğini Ehl-i beyt ve Hz. Ali ile ilgili bazı ayetlerin Kur'an'dan çıkarıldığını iddia eder. Ayrıca Sofçalıların tamamı evlerinde Kur'an bulunduğunu söylerken bir kısmında İmam Cafer Buyruğu ve Nehcü'lBelâğa bulunduğu ifade edilmiştir. Diğer taraftan cenazelerin arkasından ve mevlitlerde Kur'an okutulduğu da belirtilir. Çoğunun Kur'an okumayı bilmediği ancak çocuğunun Kur'an okumayı öğrenmesini istediği müşahede edilmektedir.

\section{Peygamberlere Iman}

Geleneksel Alevilikte peygamberlere inanılmakta, kaynaklarda bazı peygamberlerin durumlarından bahsedilmektedir (Buyruk: Imam Cafer-i Sadık Buyruğu, 2013). Ancak burada peygamberler hakkında ayrıntılı bilgi verilmez. Pîr Ahmed Ocağı dedeleri ise ilk peygamberin Hz. Âdem olduğunu daha sonra Şit peygamberin gönderildiğine inanırlar. Onlara göre Hz. Âdem ile Hz. Şit arasında peygamberlik kesintiye uğramıştır. Seyyid Kemal Ocağından Mustafa Dede ise Kur'an'da peygamberlerin Allah tarafından gönderildiğini, onların elçi olduğu ifade eder. Sofça'da ise peygamberlerin gönderilmesi konusunda tâliplerin hemfikir olduğu görülür. Burada Alevilikte çokça bahsi geçen Hızır, İlyas ve Lokman'ın peygamber olup olmadığı meselesi ortaya çıkmaktadır. Oktay Garkın Dede, Hızır ve İlyas'ın olayını anlattıktan sonra onların kullardan bir kul olduğunu, birisinin karada diğerinin denizde yardıma koşan kullar olduğunu söyler. Onların peygamber olduğunu ifade etmez. Lokman için de aynı durum söz konusudur. Mustafa Dede onların hala hayatta olduğunu belirterek Kur'an'daki bilgiye inandıklarını söyler. Sofçalılar arasında Hızır ve ilyas gerektiğinde insanların yardımına gelen kullardır.

Ahirete İman

Geleneksel Alevilik kaynaklarında kıyamet, berzah âlemi, cennet-cehennem, hesap günü kavramları sıkça kullanılmaktadır. Bu çerçevede kültürel kaynaklarda kıyamette hesaplaşma ve insanların birbirinden davacı olacak olması, dört kapıyı bilmeyen kişinin kıyamet gününde içerisinde bulunacağı hal, cennetin sekiz kapısının bulunması, sofunun cennetle olan bağlantısı ve cennetteki huriye benzetilmesi, imansız kişinin cennete giremeyecek olması, Hz. Âdem ve Hz. Havva'nın cennetten çıkarılma sebepleri gibi birçok konu tasvir edilmiştir. Ancak cennet ve içindekilerin keyfiyeti ile ilgili ocaklar arasında bazı farklılıklar söz konusudur. Mustafa Dede, cennet ve cehennemi ödül ve ceza sistemi olarak tanımlar. Buna göre cehennem münafıklar içindir. Hâmân, Şeddat, Übey b. Halef cehennemde daimi kalacaklardır. Sofçalıların istisnasız, öldükten sonra tekrar dirilmeye, cennet, cehenneme ve hesap vermeye inandıkları tespit edilmiştir. 
İslam'daki "Allah'ın bütün nesne ve olayları ezelî ilmiyle bilip belirlemesi" (Yavuz, 2001) anlamındaki kader inancının Sofça'daki Aleviler arasındaki anlaşılma şekli dedelerin görüşlerinde ortaya çıkmaktadır. Kemal Sultan Ocağından Mustafa Dede'ye göre deprem, sel gibi afetler kader-i mutlak kapsamındadır. Bunlar Allah'ın mutlak iradesi ile takdir edilmekte ve ortaya çıkmaktadır. Kişinin davranışları vardır ki kişi bunları iradesiyle yapar. Allah hayrı takdir eder, şerri ise takdir etmez. Dolayısıyla kişi yaptıklarından sorumludur. "Sana ne iyilik gelirse Allah'tandır. Sana ne kötülük gelirse kendindendir." (Nîsa, 4/79) ayeti bunun delilidir. Pîr Ahmed Ocağından Oktay Garkın Dede kadere inanmak gerektiğini, olacak şeylerin Allah tarafından önceden yazıldığını ve onaylandığını belirterek önceden takdir edilmeyen fiillerin meydana gelmediğini söyler. Burada bir istisna yaparak şerri takdir etme konusunda Allah'ın rızasının olmadığını ifade eder. Ayrıca kişi tüm fiillerini Allah'a havale edip ümitsizliğe düşmemelidir. Ümitsizliğe düşmenin tarikatta cezası vardır. Dedelere tâlip olan, kendisine soru sorulan Sofçalı Alevilerin tümü "Insanların kaderlerinin Allah tarafından önceden bilindiğine inanıyor musunuz?" sorusuna "evet" cevabı vermiş, "kader" konusunda ayrıntıya girmemiştir. Konuşmalardan dedelerin bahsettiği şekilde ayrıntılı bir kader anlayışının mevcut olmadığı görülmüştür.

\section{Ibadetler}

\section{Genel ibadetler}

Genel olarak Alevilik özel olarak Sofça'daki ibadet anlayışının anlaşılabilmesi Sofça Alevilerinin İslam'ın şartı olarak formüle edilen anlayışa olan bakış açısının bilinmesi gerekir. Çünkü teoride ve pratikte onların ibadet anlayışı bu konudaki kabullerinin bir neticesi olarak şekillenmiştir. Pîr Ahmed Ocağı dedesi Oktay Garkın Dede Alevilikte şeriatta olduğu gibi kelime-i şehadet, namaz, oruç, zekât ve hacdan oluşan İslam'ın beş şartı anlayışının olmadığını ifade ederek bunların karşısında dört kapı kırk makamı konumlandırır. Yani kişi Alevi olmak için dört kapı kırk makama inanmalı ve gereğini yapmalıdır. ${ }^{10}$ Alevilerde şeriattaki İslam'ın beş şartı anlayışııın olmaması bu şartların onlar tarafından reddedildiği anlamına gelmez. Seyyid Kemal Sultan Ocağından Mustafa Dede İslam'ın şartları arasında kelime-i şehadet, namaz kılmak, oruç tutmak, hac etmek, zekât vermeği sayar, ayrıca bunlara cünüplükten temizlenmeyi de ilave eder. Ocaklar arasındaki bu bakış farklılığı ibadetler konusunda doğal olarak farklı inanç ve uygulamalara sebep olmuş görünmektedir.

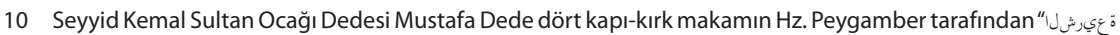

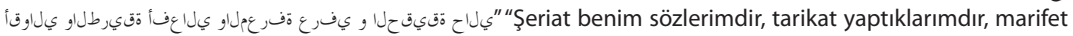
ilmimdir, hakikat halim, ahlakımdır" şekline ifade edildiğini belirtir. Ona göre insanlar bu dört kapıya bağlı kırk makamda Allah'a ulaşır. İlk kapı "Şeriat"ın inanmak, ilim öğrenmek, ibadet etmek, helal kazanç yemek, haramdan sakınmak, hayızlı hallerinde kadınlara yaklaşmamak, şeriat evine girmek, şefkatli davranmak, temiz yiyip, temiz giyinmek ve iyi şeyleri emretmek üzere on makamı vardır. İkinci kapı “Tarikat"ın mürşitten el alıp tevbe etmek, tâlip olmak, dünya nimetlerine önem vermemek, sabırlı olmak, saygılı olmak, Allah'tan korkmak, Tanrı'dan umut kesmemek, hidayet içinde olmak, toplum içinde uyumlu olmak, insanları sevip yoksulluğu seçmek gibi makamları vardır. "Mârifet" üçüncü kapı olup on adet makamı vardır: Edepli olmak, heybet, sabır ve namazla Allah'tan yardım istemek, kanaat göstermek, hayâlı olmak, cömertlik, ilim sahibi olmak, teslimiyet ve rıza, mârifet ve kendi özünü bilmek. Dördüncü kapı “Hakîkat”ın makamları ise türap olmak, Muhammed-Ali yoluna boyun eğmek, eline-diline-beline sahip olmak, güvenilir olmak, tevekkül, sohbet, sır, rıza, tefekkür ve Tanrı hasretini kalpte canlı tutmaktır (Buyruk: Imam Cafer-i Sadık Buyruğu 2013; Üzüm 2013). 
Namaz

Sofça'da yapılan gözlem ve mülakatlar neticesinde Sofçalıların namaz vakitlerinde camiye gelmediği, ara sıra bir-iki cemaatin geldiği tespit edilmiştir. Bunun yanında Cuma namazlarında bu sayı yedi ile on kişiye kadar çıkar. "Namaz hakkındaki düşünceniz nedir?" diye sorduğumuz tüm ocakların tâlipleri "beş vakit namazın kılınması gerektiğine inandığını" söyleyerek namazı kabul ettiklerini ifade etmişlerdir. Seyyid Kemal Sultan tâliplerinin dedelerinin anlayışına" uygun olarak namaz kılmaya özen gösterdikleri, Koçulu ocağı tâliplerinin ise uygulama konusunda esnek davrandıkları görülmektedir.

İslam ibadet anlayışında namaz ile abdestin birbirini tamamlayan iki unsur olması sebebiyle Alevilikte abdest anlayışı da bilinmelidir. Buyruğa göre kişi sofu olabilmek için abdestli olmalı, sofu da pir ve mürebbinin yanına abdestsiz girmemelidir. Ayrıca Buyruk'ta abdest, dört kapı kırk makam anlayışı çerçevesinde değerlendirilmiştir. Buna göre, şeriat abdesti su ile olur. Tarikat abdesti pire biat etmektir. Mârifet abdesti nefsini bilip Rabb'ini tanımaktır. Hakîkat abdesti kendi ayıplarını görüp başkalarının ayıbını örtmektir (Buyruk: Imam Cafer-i Sadık Buyruğu, 2013). Mustafa Dede, namaz abdesti almanın farz olduğunu belirterek abdestteki her bir uzvu yıkamanın bir anlamı olduğunu söyler. ${ }^{12}$ Tâlipler tarikat abdestini her yıl almalıdır. Tarikat abdesti almak demek her yıl cemde görülmektir. Diğer taraftan tâlipler namaz abdesti alarak namaza iştirak ederler. Bunun dışında cemlere abdestli girilir. Mustafa Dede'nin söylediklerinin bir benzeri Oktay Garkın Dede tarafından da dile getirilmiş, abdestin farz olduğu söylenmiştir. Ayrıca abdest alırken Mustafa Dede'nin dualarının benzerinin okunduğunu söyler. Sofçalılara abdestin gerekliliği sorulduğunda tüm ocaklara mensup tâlipler abdestin gerekli olduğunu söylemektedirler.

Diğer bir abdest çeşidi olan gusül abdesti Buyruk'ta farklı şekilde anlatılmıştır. ${ }^{13}$ Bununla birlikte İslam'daki anlamıyla gusül abdestinin farz olduğu diğer ocaklar tarafından da kabul edilmektedir. Mustafa Dede Kur'an'ı referans göstererek “Eğer cünüp iseniz, iyice yıkanarak temizlenin." (Mâide, 5/6) ayeti sebebiyle guslün farz olduğunu, ceme gusül abdesti alınarak gelindiğini söyler. "Gusül abdesti hakkındaki durumunuz aşağıdakilerden hangisidir?" sorusuna Sofçalı Alevilerin tamamı "Gerektirdiğinde gusül abdestini mutlaka alırım." şeklinde cevap vermişlerdir.

11 Mustafa Dede, sekiz yıl Kur'an kursunda okuduğunu, dedesinin on bir yaşında iken kendisini imamete geçirdiğini, arkasında namaz kıldığını anlatır. Bu anlatım Kemal Sultan Ocağının geçmişten günümüze namaz anlayışını göstermesi açısından önemlidir.

12 Kişi ellerini yıkadığında "Allah’ım verdiğin elleri haram ve kötüye kullandırma", ağzına su aldığında"Yâ Rabbi bana haram yedirme", burnuna su aldığında "Yâ Rabbi bana haram koklatma", yüzünü yıkadığında "Yâ Rabbi bana kötünün ve cehennemin yüzünü gösterme", sağ kolunu yıkarken "Yâ Rabbi sırat üzerinde giderken amel defterini sağ tarafından verdiklerinden eyle", sol kolunu yıkarken "Yâ Rabbi amel defterini sol taraftan verdiğin kullarından eyleme, harama kol uzattırma", başını mesh ettiğinde "Yâ Rabbi bana verdiğin akılla kötülükleri düşündürme", kulakları meshederken "Yâ Rabbi kötü söz işittirme", boyuna mesh ederken "Yâ Rabbi dünyaya gönül bağlayıp âhireti unutanlardan eyleme", ayakları yıkadığında "Yâ Rabbi beni kötü yol da yürütme" demektedir.

13 "Hırkanın guslü nedir?" Sorusu "Hırkanın guslü dünya uğraşından temizliktir." Şeklinde cevaplanmıştır (Buyruk: Imam Cafer-i Sadık Buyruğu 2013). 
Oruç

Alevilikte diğer ibadetlerde olduğu gibi oruç konusunda da bâtıni yorumlar bulunmaktadır. Buyruk'ta Sofunun orucu mürşide saygı göstermesi şeklinde tasvir edilmiş, bazı kaynaklarda Şeriat kapısının 3. makamı olarak zikredilmiştir (Buyruk: Imam Cafer-i Sadık Buyruğu, 2013). Ancak orucun çeşidi ve niteliği ile ilgili herhangi bir bilgi verilmemiştir. Buna bağlı olarak Alevi kabul ve uygulamalarında oruç farklı anlaşılmış, yeni anlayışlar ortaya konulmuştur.

Pîr Ahmed Ocağından Oktay Garkın Dede oruç emrinin var olduğunu, emrin Hz. Peygamber elli altı yaşında iken geldiğini belirterek Hz. Peygamber'in Risâlet'inden itibaren elli altı yaşına kadar hangi orucu tuttuğunun cevaplanması gereken bir soru olduğunu belirtir. Kur'an'da emredilen (Bakara, 2/183) oruç Ramazan orucu değildir. Burada oruç emri söz konusudur. Farz olan orucun Muharrem orucu olduğu yine ayetlerle açıklanmıştır. ${ }^{14}$ Aynı durum Hz. Muhammed'in hadisleriyle de tespit edilmiştir. Bu sebeple Muharrem orucunu tutmak farzdır. On veya on iki gün şeklinde tutulur. Orucun başlaması-bitişi, tutulma keyfiyeti konusunda İslam'daki anlayıştan farklı uygulamalar görülür. Buna göre Muharrem orucunda sahur yapılmaz. Matem olması sebebiyle oruç esnasında su içilmez, cana zarar verilmez, kesilmiş mahlûk yenilmez. Ayrıca 15-16 Aralık'ta İmam Hasan için iki gün, 18-1920 Ocak'ta Hz. Ali için üç gün, 13-14-15 Şubat'ta Hz. Hüseyin ve Hızır (Hızır orucu) için üç gün, 10-11 Mayıs'ta Hızır-ilyas için iki gün oruç tutulur.

Seyyid Kemal Sultan Dedesi Mustafa Dede ise bu konuda Pîr Ahmed Ocağının anlayışından farklı olarak Kur'an'da Ramazan orucunun emredildiğini bu sebeple orucun farz olduğunu söyler. Buradan orucun tutulma şeklinden bahseden Mustafa Dede, orucun İslam'daki gibi sahur ve iftar yaparak, yeme, içme ve benzeri şeylerden uzaklaşarak tutulması gerektiğini ifade eder. Muharrem orucu ocağa göre sünnet-i müekkede olup farz değildir. On iki gün şeklinde tutulur. Kırk sekiz Perşembe, Hızır orucu gibi oruçlar yoktur ancak tâlip isterse bu günlerde oruç tutabilir. ${ }^{15}$

Sofçalıların oruç ibadeti ile ilgili pratikleri ocaklardaki bu anlayış ile yakınlık göstermektedir. Seyyid Kemal Ocağı tâliplerinin Ramazan ve muharrem orucunu tuttukları ifadelerinden anlaşıımış, Koçulu ocağı tâliplerinin yarısının Ramazan ve Muharrem orucunun tutulması gerektiğine inandığı, her ikisini de tutmaya çalıştığı belirtilmiştir. Koçulu'dan diğer kısım ise sadece Muharrem ve Hızır oruçlarını tutmaya çalıştığını beyan eder. Sofça'da orucun varlığı ve farziyeti konusunda ihtilaf olmasa da uygulamada genel itibariyle gevşeklik görülmektedir.

\section{Zekât}

Alevi kaynaklarında hakkında fazla bilgi bulunmayan zekâtın varlığını ve verilmesi gerektiği konusunda vurgulu açıklamayı Seyyid Kemal Sultan Ocağı Dedesi Mustafa Dede yapmaktadır. Ancak kültürel kaynaklarda olduğu gibi zekâtın mahiyetine ve nasıl verilmesi gerektiği konusuna girilmez. Pîr Ahmed Ocağında ise İslam'da malın kırkta birinin verilmesi şeklindeki bir zekât anlayışının olmadığı ifade edilir. Bunun yerine zekâttan maksadın yardımlaşma ve paylaşım olduğu zikredilir. Sofçalılar arasında da ocaklardaki bu anlayışın yansıması olarak zekâttan ziyade fakirlere yardım, sadaka, aşure dağıtmak gibi yardımlaşma faaliyetleri ön plana çıkar.

15 Mustafa Dede, mertebeleri anlamında orucu tarikatlardakine benzetir. Ona göre oruç avam, havâs ve havâssu'l-havas olmak üzere üçe ayrılır. 
$\mathrm{Hac}$

Arafat'ta vakfe yapma ve Kâbe'yi tavaf etme şeklindeki hac anlayışı Pîr Ahmed Ocağında bulunmaz. Dedelerin ifadesiyle bir Alevi kutsal mekân olmaları sebebiyle Mekke ve Medine'ye gidebilir ancak hac için gitmek mecburi değildir. Bu anlayışlarının temelinde Hak-Muhammed-Ali konusunda bahsedilen varlığın birliği, vahdet-i vücud anlayışı ve insanın merkezi bir konuma konulması vardır. Allah ve varlık bir bütündür. İnsanın gönlü Allah'ın evidir. Dolayısıyla Allah insanın gönlünde taşınır. Bu anlayışa göre Allah'ı arayan insan kendine bakmalıdır. ${ }^{16}$ Seyyid Kemal Sultan Ocağında ise İslam'daki anlamıyla hac vardır ve farzdır. Sofçalı Alevilere "Imkânınız olsa ilk önce nereyi ziyaret ederdiniz?" diye sorulduğunda ilk sırada Mekke (Kâbe), Medine'nin (Mescid-i Nebevî) zikredildiği, buralara gitme isteğinin tâlipler arasında kuvvetli olduğu görülür. Ardından Kerbelâ, daha sonra Nevşehir'i (Hacı Bektaş Veli Türbesi) ziyaret en fazla verilen cevap olmuştur. Bazı Aleviler hacca gittiklerini ifade etmişlerdir.

\section{Âdap-Erkan}

Alevilik tarikat esasları çerçevesinde şekillenmiş bir yapıdır. Bu sebeple tasavvuftaki usul ve uygulamaları Aleviler, Müslüman olmadan önceki inanç ve adetleriyle birleştirmişlerdir. Bunun neticesinde yeni bazı usul ve uygulamalar ortaya çıkmışır. Âdap ve erkân da denilen bu usul ve uygulamaların esası cem olup birçok âdap ve erkân bunun etrafında şekillenmiştir. Cemin anlaşılabilmesi için Alevilikteki hiyerarşik yapı bilinmelidir. Çünkü cemin içerisindeki birçok uygulama dede, rehber ve tâlip ekseninde gerçekleşmektedir. illk dönemlerde üstten aşağıya doğru halife, dede, mürebbi, rehber, musahip ve tâlip şeklinde oluşmakta olan hiyerarşi bugün çoğunlukla dedelik, rehberlik ve tâliplik şeklinde görülür. Burada halifelik makamını Bektâşî çelebisi temsil etmektedir. Dedeler de mürşitlik, pirlik ve mürebbilik görevlerini yerine getirmektedir (Üzüm, 2013). Bu durum Sofça'daki Aleviler için de söz konusudur. Daha önce ifade edildiği üzere Pîr Ahmed Efendi Ocağında tâliplerin işleri en büyükleri olan Ali Garkın Dede, Oktay Garkın Dede ve Ali Rıza Dede tarafından yürütülmektedir. Koçulu Ocağında ise Ali Rıza Dede'nin vefatı üzerine yeni dedenin belli olması beklenmektedir. Seyyid Kemal Ocağında ise Mustafa ve Ali Dedeler dedelik makamında bulunmaktadır. Ali Garkın Dede'nin ifadesiyle hiyerarşik yapıda; Allah'ın vekili Muhammed, Muhammed'in vekili Ali, Ali'nin vekili pirler, pirlerin vekili mürşitler, mürşitlerin vekili dedelerdir. Dedeler Hz. Peygamber soyundan gelmelidir. Ellerinde bunu gösteren bir belge, $\mathrm{Hz}$. Peygamber'e kadar uzanan bir şecere bulunmalıdır. Rehber dedenin yardımcısı, tâlibe yol gösteren, tâlibi yola getiren kişidir. Tâlip ise yol mensubu anlamına gelmekle birlikte Ali'ye sahip çıkan ve onu seven anlamındadır.

\section{Cem Erkânı}

Tâliplerin bir araya gelerek evliya erkânını icra etmesi olarak tanımlanan (Kaplan, 2011b) cemlerin kökeninde "kırklar cemi" adı verilen mitolojik olay dikkati çeker. Hz. Muhammed'in Miraç'ta veya Miraç sonrası Hz. Ali'nin sırrına vakıf olması, Kırklarla tanışması anlamına gelen

16 Ali Garkın Dede burada Hacı Bektaş-ı Veli'den "Hararet nardadır, saçta değil/ Keramet hırkada, taçta değil/ Mevlâ'yı ararsan, içinde ara/ Kudüs'te, Mekke'de, hacda değil" dörtlüğünü nakleder. 
Kırklar cemi Buyruk'ta anlatılmaktadır. Pîr Ahmed Ocağı ve Seyyid Kemal Ocağı dedeleri cemi tarif ederken kırklar ceminde ve bu süreçte meydana gelen olayları anlatırlar. Buna göre Hz. Muhammed Miraç'a giderken kendisine karşı kükreyen bir aslanla karşılaşır. $\mathrm{Ne}$ yapacağını şaşıran Hz. Muhammed, yüzüğünü aslanın ağzına vermesini isteyen bir ses duyar. Söylenileni yapan $\mathrm{Hz}$. Muhammed, aslanın sakinleşmesi üzerine yoluna devam eder. Göğün en yüksek katında dostuyla buluşur, onunla doksan bin kelam eder, burada bazı olaylar meydana gelir. Miraçtan dönüş yolculuğuna başlayan $\mathrm{Hz}$. Muhammed, şehirde ilgisini çeken bir kubbe görür. Bunun üzerine kubbenin kapısına geldiğinde içeride birilerinin sohbet ettiğini görür. İçeri girmek için kapıyı vurduğunda kim olduğu ve geliş sebebi sorulur. $O$ da peygamber olduğunu ifade edince peygamberin aralarına sığmayacağı söylenir ve kapı açılmaz. Oradan ayrılacağı sırada tekrar kapıya doğru gitmesi Tanrı tarafından istenince geri döner. İçeriden kim olduğu sorulunca peygamber olduğunu söylemesi üzerine yine kapı açılmaz. Üçüncü defa çalınca kendisini tanıtırken yoktan var olmuş bir yoksulun oğlu olduğunu söyleyince kapı açıır. Bu esnada yirmi ikisi er, on yedisi bacı otuz dokuz can oturmaktadır. Hz. Muhammed kimin yanına oturduğunu bilmeden $\mathrm{Hz}$. Ali'nin yanına oturur. Merak ederek onların kim olduğunu sorar. "Biz Kırklarız" cevabını alır. Otuz dokuz kişi olduklarını söylediğinde Selman'ı aramızda say derler. Bunun ispatını isteyen Hz. Muhammed'e göstermek için Hz. Ali'nin kolundan kan akıtılır. Bu esnada tüm Kırkların kolundan kan gelmektedir. Selman'ın kolunun kanı da pencereden bir damla şeklinde damlar. Bu sırada elinde bir üzüm tanesiyle Selman gelir. Hz. Muhammed'den mecliste bulunanlara bu üzüm tanesini paylaştırmasını isterler. Hz. Muhammed Allah'ın cennetten gönderdiği bir tabak içerisinde üzüm tanesini ezip şerbet yapar. Kırklar o şerbetten içince sarhoş olup ayağa kalkar. Üryan büryan semaha girer. Bu esnada Hz. Muhammed de semaha girer. Semah esnasında Hz. Muhammed'in başından imamesi düşünce kırk parçaya ayrılır. Kırkların her biri imamenin bir parçasını alarak etek yapıp kuşanır. Kırkların piri ve rehberini soran $\mathrm{Hz}$. Muhammed'e pirlerinin $\mathrm{Hz}$. Ali, rehberlerinin Cebrâil olduğu söylenir. Bunu üzerine $\mathrm{Hz}$. Muhammed Hz. Ali'nin orada olduğunu anlar. Kendisine doğru gelen Hz. Ali'ye saygıyla yer gösterirken onun parmağında Miraç'a çıkarken aslanın ağzına verdiği yüzüğü görür (Buyruk: Imam Cafer-i Sadık Buyruğu, 2013).

Yukarıda kaynağı anlatılan cem toplantısı düzenlenirken on iki hizmet adı verilen erkânı yerine getirmek gereklidir. On iki hizmetin yerine getirilmediği cem hakikatte gerçekleşmemiş kabul edilir (Üzüm, 2013). Bu hizmetler küçük bazı farklııılar dışında tüm ocaklarda aynıdır. Seyyid Kemal Sultan Ocağından Mustafa Dede on iki hizmeti temsil ettiği imamlarla birlikte şöyle anlatır: Mürşid-Hz. Muhammed Mustafa (s.a.v.), rehber-Hz.Ali el-Mürtezâ, gözcü-Cebrâil, çırakcı-Câbirü'l-Ensâr, zâkir-Bilâl-i Habeşî, ferraşçı-Selmân-ı Pak, kurbancıMahmûd el-Ensarî, sakkacı-Imam Hüseyin, ibriktar-Gulâm-ı Kamber, peyk-Ammâr-ı Ayyâr, semahçı-Ebu Zerri'l-Gıfârî'dir. On iki hizmetin başındaki dede, cemi yönetir. Rehber dedenin yardımcısıdır, ceme katılanlara yardımcı olur. Gözcü cemde olur, düzeni ve sükûneti sağlar. Çırakçı mum yakar, meydanı aydınlatır. Zakir deyiş, düvaz söyler. Ferraşçı süpürge çalar. Kurbancı kurban ve yemek işleri ile ilgilenir. İbriktar-sakkacı el suyu dağıtır. Semahçı semah yapar, Peyk cemi tâliplere haber verir. İznikçi cem mekânının temizliği ile ilgilenir. Bekçi cem ile ceme iştirak edenlerin evini korur. Hizmetkârlar ikrarlı olmak zorundadır. Belli olması için ikrarlı olanların koluna bir bent takılır. 


\section{İkrar-Görgü-Musahiplik-Dârdan Indirme ve Düşkünlük Erkânı}

Alevilikte zaman zaman farklı amaçlar için cemler düzenlenmektedir. Pîr Ahmed Ocağı dedesi Oktay Garkın Dede'ye göre cem olmak belirli şartlar çerçevesinde toplanmak demektir. Cemde birlik ve beraberlik hâkim olup buna zarar gelmemesi için toplum tarafından tanınmayan kişiler ceme alınmaz. Ayrıca cem olmak katılanların mümin olmasını gerektirir. ${ }^{17}$ Kişi mümin oluncaya kadar tâliptir. İkrar vermesiyle birlikte mümin olur. Ali Garkın Dede'ye göre ikrar, oruç demektir. Çünkü tâlip vermiş olduğu sözü tutmalıdır. Aleviler arasında hakiki anlamda Alevi olabilmek için verilmesi gereken ikrar ikrar cemi olarak adlandırılan bir cemde verilir. Mustafa Dede'ye göre Allah'a ve Resûlullah'ın sünnetine saygı duyan, onun yolu üzere yaşayan, namazını kılan, orucunu tutan, ehl-i beyte gönül veren, yoluna ve erkânına bağlı olan, Kur'an ahlakı üzerine olan herkes ikrar vererek yola girebilir. ${ }^{18}$ ikrarın temelinde $\mathrm{Hz}$. Peygamber'in Akabe'de Medineli Müslümanlardan almış olduğu söz vardır.

Sofçalı Alevilerle yapılan anket ve mülakat neticesinde ikrar verenlerin çoğunlukta olduğu, ancak az da olsa ikrar vermeyenlerin bulunduğu tespit edilmiştir. Buna göre ikrar verenlerin orta yaş ve üstü, vermeyenlerin ise orta yaş altındaki Sofçalılardan oluştuğu görülür. Bu da genç nesil arasında Aleviliğin erkânına olan bağlıı̆ın zayıflaması olarak yorumlanabilir. "Ailenizde Alevi inancına bağlııı durumu nasıldır?" sorusuna verilen cevaplar da bu sonucu destekler mahiyettedir.

Alevilik erkânından bir diğeri de musahiplik erkânıdır. Evli iki çiftin yol kardeşliği kurması anlamına gelen bu erkânın temelinde ensar ile muhacir ve Hz. Muhammed ile Hz. Ali'nin kardeş olması vardır. Ocak dedelerinin ifadelerine göre musahiplik kan kardeşliğinden daha ileri seviyede, mezara kadar devam eden bir kardeşliktir. Bu kardeşlik hukuku yedi göbek aile fertlerini bağlar. Musahip olan iki can birbirinden kız alıp veremez. Kazançları ortak olup zengin olan fakir olana yoksulluğunu hissettirmez. Birbirlerinin evlerine davet edilmeden girerler. Onlar için mükâfat ve cezalar da ortaktır. Dolayısıyla birbirleriyle her şeylerini paylaşırlar.

Alevilikte musahip olmak için merasim düzenlenmesi gereklidir. Musahip kardeşini seçen canlar cem esnasında Hakk'ın huzurunda, halkın ve dedenin önünde musahipliğin şartlarını yerine getirme hususunda yemin ettirilir. Gerekli ritüellerin yerine getirilmesinin ardından musahiplik tesis edilmiş olur. Musahipliğin şartlarını yerine getirmeyen kişi düşkün konumuna düşer ve ebedi olarak yola kabul edilmez. Sofça Alevilerinden Koçulu Ocağına bağlı bir tâlip musahibi olduğunu ifade etmiş, diğerleri musahiplerinin olmadığını beyan etmiştir. Her Alevi'nin musahibinin olması gerekirken çoğu talibin musahibinin olmaması hatta bazı dedelerin de musahibinin olmadığını ifade etmesi musahipliğin günümüz şartlarında uygulanabilirlik durumunun zor olması ile izah edilmektedir. Pîr Ahmed Ocağı Dedeleri Alevi toplum fertlerinin dağınık ortamlarda yaşamasının bu erkânın ihmal edilmesinin en önemli sebeplerinden birisi olduğunu ifade eder. Çünkü musahiplik namus hariç her şeyi paylaşmak anlamına geldiğinden aynı ortamda olmayan insanların musahip olması da zorlaşmaktadır. ${ }^{19}$

17 Ali Garkın Dede, müslüman-mümin kavramlarını tanımlarken Müslümanın genel bir kavram olduğunu, Alevî́nin ise mümin olmak için Ali'ye tabi olması gerekliğini söyler. Bunu da Hz. Peygamber'in "Ben ilim şehriyim; Ali ise kapısıdır." sözüyle gerekçelendirir.

Burada Bektaşîlikteki anlayışa uygun bir kabul söz konusudur.

Mustafa Dede musahibi olmayanlara iki kapılı, olanlara ise dört kapılı denildiğini ifade eder. 
Alevilerin erkânlarından bir diğeri dârdan indirmedir. Vefat eden kişi için helallik almak amacıyla yapılan toplantıya dârdan indirme denir (Üzüm, 2013). Mustafa Dede, sağlığında Hz. Peygamber'in helalleştiğini belirterek "dâr"ın ölüyü kul hakkından arındırmak olduğunu ifade eder. Buna göre dârdan indirme, vefat eden kişinin velisi veya vasisinin mürşid huzuruna gelerek velisi veya vasisi olduğu beyan etmesi, mevtanın alacağı varsa onu alacağına, borcu varsa vereceğine, mirası varsa kardeşleri arasında adaletli bir şekilde paylaştıracağına dair söz vermesi ve bunu yerine getirerek helallik almasıdır. Dârdan indirme esnasında mevtaya kefil olan kimse, cemden sonraki bir zamanda kefil olduğu kişinin alacaklıları çıkarsa bunu karşılamak zorundadır. Diğer taraftan dâra veli veya vasilerden bir kişi durur ve kefilliği bir kişi üstlenir. Bazı zamanlar diğer mirasçılardan dâra duranlar olabilir. Ancak kefilliği üstlenen içlerinden birisidir. Helalleşme kul hakları için söz konusu olup kul hakkı dışındaki Allah hakkı için dâra durulmaz. Pîr Ahmed Ocağında bu erkân şöyle yerine getirilir: Anne veya babası vefat eden vasi halkı davet eder, bu arada kurban keser. Dede "Ey canlar alacaklı verecekli var mı?" diye sorar. "Varsa gelsin dil olsun meydana gelsin" der. Bu arada alacaklı varsa bunu söyler. Yoksa "Allah, eyvallah" der. Bunu üç defa tekrarlar. Sonra dede dua ile dârdan indirmeyi yerine getirir.

Alevi erkânlarından birisi de düşkünlüktür. Vermiş olduğu sözde durmayan, cezalandırılmış talibe düşkün denir. Düşkünlük kendiliğinden gerçekleşen bir durum olmayıp Alevi halk önünde gerçekleşir. Dede gelen şikâyetler üzerine halkı toplayarak şikâyet konusu olan meseleyi halkın bilgisine sunar. Düşkün olmayı gerektirecek suç sabit olursa halkın kararıyla kişinin düşkün olmasına karar verilir. Düşkün konumuna düşmüş ancak pişman olmuş kişinin tekrar yola girmesi, topluma kabul edilmesi yola dönüş şartlarını yerine getirmesi durumunda mümkündür. Ali Garkın Dede, eski zamanlarda pişman olan tâliplerin geri dönüşü için tertip edilen bazı uygulamaların günümüzde yapılmadığını söyler. ${ }^{20}$ Mustafa Dede de düşkün olmayı ve cezalandııımayı gerektiren durumlarda Kemal Sultan Ocağı'nda toplumun kendi içerisinde bu kişiyi cezalandırdığını belirterek, geçmişten gelen uygulamaların da devam ettiğini söyler. Alevi ocakları arasında düşkün olmayı gerektiren meseleler genel itibariyle birbirine benzese de verilen cezaların nitelik ve niceliğinde bazı farklılıkların olduğu müşahede edilmektedir. Diğer taraftan Sofça halkının farklı yerlerde yaşaması, birbirleriyle olan irtibatının zayıflaması doğal olarak düşkünlük erkânının da uygulanabilirliğini etkilemiş görünmektedir.

20 Oktay Garkın Dede Pîr Ahmed Ocağındaki suç ve cezalarının Kur'an ve İmam Cafer Buyruğu'na göre belirlendiğini, fiilen uygulandığını söyleyerek suçlar ve cezaları şöyle nakleder: Suçlar: Cana kıyan ömür boyu yoldan düşkün olur. Zina eden on yıl yoldan düşer, seksen değnek vurulur. Zinaya teşebbüs eden iki yıl yoldan düşkün olur, seksen değnek vurulur. Hırsızlık yapan beş yıl yoldan düşer, çaldığı malı öder. Kumar oynayan ve kumara teşvik eden iki yıl yoldan düşer, iki çeyrek altın cezası öder (Ceza fakirlere, öksüz ve yetimlere, vakıf ve benzeri yerlere verilir.). Ifttira atan, yalancı şahitlik yapan bir yıl düşkün olur, iki çeyrek altın ceza öder. Suçsuz yere eşini boşayan beş yıl düşkün olur. Anlaşmalı boşanmalarda ise iki yıl düşkün olur. Yetim malı yiyen, iki yıl düşkün olur, ceza bitimi bir kurban keser. Ana-babaya kötü davranmak, Önce tembih edilir, sonra ihtar verilir, devamında bir büyük altın cezası öder. İnkâr eden, ihanet eden ve şirk koşan yoldan düşer. Üfürükçülük yapan önce ihtar edilir, devam ederse beş yıl düşkün kalır (Tevbe eder, toplum kabul ederse bir kurban keserek yola devam edebilir.). Allah'tan ümit kesen yoldan düşer. Kin, kibir sahibi olan tembih edilir, ihtar verilir. Komşu hakkına saygısızlık yapana ihtar verilir, komşusundan helallik alır. Fitne fesatlık edene, önce ihtar verilir. Devamında çeyrek altın cezası öder. Zan besleyen, gıybet eden, çekememezlik yapan önce ihtar edilir. Devam ederse yirmi değnek vurulur. Yol kardeşiyle muti olmayan önce tembih edilir, devam ederse bir küçük altın öder, yol kardeşinden özür dileyerek helallik alır. 


\section{Sonuç}

Sünni ve Alevi çevrelerde itibar gören Pîr Ahmed Efendi tasavvuf hilafetine sahip bir kişidir. O, ilk önce Karamanlı Cem Seyyah'tan daha sonra İstanbul'da Sümbül Sinan'dan eğitim almış, burada hilafet alarak Kalburcu köyüne gelerek irşat vazifesine başlamıştır. Oğlu Şeyh Beşir ile torunu Müftî Derviş olarak bilinen Şeyh Ahmet Halvetî gelenek içerisinden gelmektedir. Aynı şekilde Sunullâh-ı Gaybî de Halvetîliğin önemli bir temsilcisi olarak görülmektedir.

Oğlu ve ahfadının Halvetî gelenekten geldiği sabit olmasına rağmen günümüzde Pîr Ahmed Efendi'nin türbesinin bulunduğu Sofça ve civarında onun Alevilerce itibar edilen bir kişi olduğu müşahede edilmektedir. Her yıl onun adına etkinlikler düzenlenmekte, yemek dağıtılmakta, semah gösterileri sunulmaktadır. Sofça, Kütahya ve Eskişehir gibi civar şehirlerdeki Sofçalıların Koçulu, Seyyid Kemal Sultan ocaklarına mensup oldukları görülmektedir. Aynı şekilde Pîr Ahmed Efendi'nin adıyla anılan bir ocak bulunsa da Sofça'da bu ocağın tâlipleri bulunmamaktadır. Ancak Yeni Sofça ve yakın köylerde tâlipler bulunmaktadır.

Sofça cemevinde yılda bir kez cem töreni düzenlenmeye çalışılmakta tüm ocak tâliplerinin katılımı için gün, iletişim ve ulaşımın ayarlaması yapılmaktadır. Ayrıca Ulusal Pîr Ahmet Efendi Anma ve Kültür Festivali'nde de cem töreni düzenlenmektedir. Buradaki cem törenleri iki bölümden oluşmakta ilk bölüm umuma açık iken ikinci bölüme sadece ikrarlı Aleviler katılabilmektedir.

Yerinde yapılan mülakatlarda Sofçalıların tamamına yakının kendisini Alevi inancına bağlı kabul ettiği, inanç yönünden ise kendilerini Alevi olarak tanımladıkları görülmüştür. Aynı şekilde Aleviliğin tarikat ya da mezhep oluşuyla ilgili dedelerdeki net bilgiler tâliplerde görülememektedir. Dedeler Aleviliği tarikat olarak tanımlarken Sofçalılar bu konuda homojen bir yapı sergilemez. Tarikat ve inanç sitemi tanımlaması ağırlıklı olarak yapılmaktadır. Tâliplerden Aleviliği mezhep olarak kabul edenler yok denecek kadar azdır. Bunun sebebinin tâliplerin Alevilik hakkında çok fazla bilgi sahibi olmamaları, bilgilerini anne-baba ve dedelerinden almaları olabilir.

Ayrıca Ali anlayışı yönüyle Sofçalıların zihin ve inançlarının net olduğu görülür. Onlara göre Ali, Allah'ın bir kulu olup tanrısallıkla hiç bir ilgisi yoktur. Onlar temel inanç esaslarını yani Allah'a, meleklere, kitaplara, peygamberlere, ahiret gününe, kaza ve kadere imanı kabul etmekle birlikte bunların bazılarını kendi tasavvuf, örf ve adetlerinden kaynaklanan etki ile kendine has formda değerlendirirler. İbadet esasları yönüyle de aynı durum geçerlidir. İslam'daki namaz, oruç, zekât gibi ibadetleri kabul etmekle birlikte uygulama bakımından farklı değerlendirmeler yapılır. Bu sebeple ibadetler konusunda gevşek bir anlayış söz konusudur.

Kendileri dışındaki kişilerle iletişimlerinin iyi olduğu, birbirlerinin önemli günlerine katılım gösterdikleri, gerektiği zaman mevlit okuttukları belirtilmektedir. Ayrıca köy imamı, çocukların isimlerinin konulması, mevlit okunması gibi hususlarda aktif görev almaktadır. Eskiden kendileri dışındaki gruba mensup insanlarla evliliğe olumlu bakılmaz iken şartların değişmesi üzerine bu konuda esnek bir yapı oluştuğu müşahede edilmiştir. Diğer taraftan insanların farklı yerlerde ikamet etmeleri, teknolojinin gelişmesi vs. sebeplerle Sofça'daki adet, gelenek ve inanışların yaşatılmasında eksiklikler görülmektedir. Bu durum Alevi büyükleri arasında çözülmesi gereken bir konu olarak ele alınır.

Hakkında çok fazla bilgi olmayan Pîr Ahmed Efendi dönemini incelemek için dönemin vakıf kayıtlarının incelenmesinin bizi yeni bilgilere ulaştıracağı kanaatindeyiz. Ayrıca Halvetî bir geleneğe kaynaklık yapmış bir kişiliğin Alevilikle irtibatlandırılma sebeplerini tespit için Halvetîlik-Alevilik münasebeti üzerine ayrı bir çalışma yapılması faydalı olacaktır. 


\section{Kaynak Kişiler}

\begin{tabular}{|c|c|c|c|c|c|c|c|}
\hline 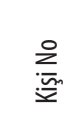 & $\begin{array}{l}\overline{\bar{\sigma}} \\
\text { 离 } \\
\text { 훈 }\end{array}$ & $\approx$ & 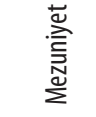 & 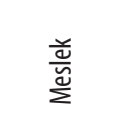 & 司 & : & 总 \\
\hline (K.1) & $\begin{array}{l}\text { Ahmet } \\
\text { Özcan }\end{array}$ & 52 & İlkokul & Emekli & Koçulu Ocağı & Sofça Köyü & $\begin{array}{l}17 \text { Eylül } 2015 \text { ve } 28 \\
\text { Şubat } 2016 \text { tarihli } \\
\text { görüşmeler }\end{array}$ \\
\hline (K.2) & $\begin{array}{l}\text { Ali Ekber } \\
\text { Yiğit }\end{array}$ & 51 & Lise & $\begin{array}{l}\text { Çiftçi/ } \\
\text { Muhtar }\end{array}$ & Koçulu Ocağı & Sofça Köyü & $\begin{array}{l}28 \text { Şubat } 2016 \text { tarihli } \\
\text { görüşme }\end{array}$ \\
\hline (K.3) & Ali Erhan & 62 & İlkokul & $\begin{array}{l}\text { Çiftçi/ } \\
\text { Emekli }\end{array}$ & $\begin{array}{l}\text { Seyyid Kemal } \\
\text { Sultan Ocağı }\end{array}$ & Sofça Köyü & $\begin{array}{l}28 \text { Şubat } 2016 \text { tarihli } \\
\text { görüşme }\end{array}$ \\
\hline (K.4) & $\begin{array}{l}\text { Ali Garkın } \\
\text { Dede }\end{array}$ & 86 & --------- & Dede & $\begin{array}{l}\text { Pîr Ahmet Efendi } \\
\text { Ocağı }\end{array}$ & Avdan & $\begin{array}{l}21 \text { Şubat } 2016 \text { tarihli } \\
\text { görüşme }\end{array}$ \\
\hline (K.5) & Ali Gürbüz & 52 & İlkokul & Çiftçi & Koçulu Ocağı & Sofça Köyü & $\begin{array}{l}28 \text { Şubat } 2016 \text { tarihli } \\
\text { görüşme }\end{array}$ \\
\hline (K.6) & Arife Yiğit & 83 & İlkokul & Ev Hanımı & Koçulu Ocağı & Sofça Köyü & $\begin{array}{l}28 \text { Şubat } 2016 \text { tarihli } \\
\text { görüşme }\end{array}$ \\
\hline (K.7) & Ayfer Yiğit & 30 & Lisans & Laborant & Koçulu Ocağı & Sofça Köyü & $\begin{array}{l}28 \text { Şubat } 2016 \text { tarihli } \\
\text { görüşme }\end{array}$ \\
\hline (K.8) & $\begin{array}{l}\text { Emine } \\
\text { Erhan }\end{array}$ & 60 & İlkokul & Ev Hanımı & $\begin{array}{l}\text { Seyyid Kemal } \\
\text { Sultan Ocağı }\end{array}$ & Sofça Köyü & $\begin{array}{l}28 \text { Şubat } 2016 \text { tarihli } \\
\text { görüşme }\end{array}$ \\
\hline (K.9) & Halil Girgin & 47 & Ortaokul & İş̧̧i & Koçulu Ocağı & Sofça Köyü & $\begin{array}{l}28 \text { Şubat } 2016 \text { tarihli } \\
\text { görüşme }\end{array}$ \\
\hline (K.10) & Halil Tunca & 62 & İlkokul & Emekli & Koçulu Ocağı & Sofça Köyü & $\begin{array}{l}28 \text { Şubat } 2016 \text { tarihli } \\
\text { görüşme }\end{array}$ \\
\hline (K.11) & $\begin{array}{l}\text { Kadriye } \\
\text { Memiş }\end{array}$ & 68 & İlkokul & Emekli & Koçulu Ocağı & Sofça Köyü & $\begin{array}{l}28 \text { Şubat } 2016 \text { tarihli } \\
\text { görüşme }\end{array}$ \\
\hline (K.12) & $\begin{array}{l}\text { Mahmut } \\
\text { Çaksaz }\end{array}$ & 69 & İlkokul & $\begin{array}{l}\text { Balıçı/ } \\
\text { Emekli }\end{array}$ & Koçulu Ocağı & Sofça Köyü & $\begin{array}{l}28 \text { Şubat } 2016 \text { tarihli } \\
\text { görüşme }\end{array}$ \\
\hline (K.13) & $\begin{array}{l}\text { Mehmet Ali } \\
\text { Erhan }\end{array}$ & 83 & İlkokul & $\begin{array}{l}\text { Çiftçi/ } \\
\text { Emekli }\end{array}$ & $\begin{array}{l}\text { Seyyid Kemal } \\
\text { Sultan Ocağı }\end{array}$ & Sofça Köyü & $\begin{array}{l}28 \text { Şubat } 2016 \text { tarihli } \\
\text { görüşme }\end{array}$ \\
\hline (K.14) & $\begin{array}{l}\text { Mehmet Ali } \\
\text { Yiğgit }\end{array}$ & 67 & İlkokul & $\begin{array}{l}\text { Çiftçi/ } \\
\text { Emekli }\end{array}$ & Koçulu Ocağı & Sofça Köyü & $\begin{array}{l}28 \text { Şubat } 2016 \text { tarihli } \\
\text { görüşme }\end{array}$ \\
\hline (K.15) & $\begin{array}{l}\text { Mustafa } \\
\text { Demir } \\
\text { Dede }\end{array}$ & 66 & -------- & Dede & $\begin{array}{l}\text { Seyyid Kemal } \\
\text { Ocağı }\end{array}$ & $\begin{array}{l}\text { Afyon- } \\
\text { Alanyurt } \\
\text { Köyü } \\
\end{array}$ & $\begin{array}{l}21 \text { Şubat } 2016 \text { tarihli } \\
\text { görüşme }\end{array}$ \\
\hline (K.16) & $\begin{array}{l}\text { Oktay } \\
\text { Garkın } \\
\text { Dede }\end{array}$ & 70 & ------- & Dede & $\begin{array}{l}\text { Pîr Ahmet Efendi } \\
\text { Ocağı }\end{array}$ & Avdan & $\begin{array}{l}21 \text { Şubat } 2016 \text { tarihli } \\
\text { görüşme }\end{array}$ \\
\hline (K.17) & Sevim Yiğit & 51 & İlkokul, & Ev Hanımı & Koçulu Ocağı & Sofça Köyü & $\begin{array}{l}28 \text { Şubat } 2016 \text { tarihli } \\
\text { görüşme }\end{array}$ \\
\hline (K.18) & $\begin{array}{l}\text { Umahan } \\
\text { Yiğit }\end{array}$ & 64 & İlkokul & Ev Hanımı & Koçulu Ocağı & Sofça Köyü & $\begin{array}{l}28 \text { Şubat } 2016 \text { tarihli } \\
\text { görüsme }\end{array}$ \\
\hline
\end{tabular}




\title{
Pîr Ahmed Efendi, The Sheikh of Kalburcu, and Understanding of Alevîs in the Sample of Sofca
}

\author{
Rifat Türkel*
}

\begin{abstract}
The Alevîs have organized the "Traditional Memorial of Pîr Ahmed Efendi and Cultural Festival" since 2009 in the name of this man, who is very respected by many Alevî communities. This article provides information about him and tries to determine the understanding and perception of Sofca's residents, for his grave is preserved in their village.

The researcher consulted manuscripts, grandfathers (dede) and resource persons to determine how he is currently perceived. On the other hand, the Alevî perception of Sofca's residents and how they characterize themselves is studied in terms of the information provided by household (ocak) dedes whose Alevî followers (talip) are related to and talips from Sofca, because Pîr Ahmed Efendi has been appropriated by today's Alevîs from the Halvetîs.
\end{abstract}

\section{Introduction}

The life story of Pîr Ahmed Efendi, the Sheikh of Kalburcu, contains many gaps because the sources contain limited information. However, anecdotes and hearsay abound because he was from Kalburcu, as indicated by his title. He was also called Pîr (spiritual leader) and, so it is claimed, Mihmandar (host). Evliya Celebi visited the tomb of Pîr Ahmed Efendi, who died in 1570. The tomb was moved to its current place in 1949 so that it would not be underwater while the Porsuk dam was being constructed.

After the dam was constructed, some of Sofca's original inhabitants continued to live in what remained of their village. Source persons from Sofca relate that tomb had been in a state of disrepair for long time; however, it has been repaired and made locally famous due to the villagers' effort. Pîr Ahmed Efendî was accepted as an ocak dede in nearby districts in which lived talips who are related to that ocak. This caused the people of Sofca and other Alevî talips to be more more respectful of each other. The dedes of the Pîr Ahmed Efendi Ocak have named this place the Dede Garkın Ocak. Yet the word "wonder," which is represented in Abdal Musa's Vilayetnâme as "Allay more people's hunger with less food," is a consequence of saint (evliya) or a man of God (eren) cult.

* Assist. Prof. Dumlupınar University, Faculty of Teology, History of Islamic Sects Deparment. Correspondence: rifatturkel@gmail.com. Address: Evliya Çelebi Yerleşkesi Kamu Yönetimi Binası Tavşanlı Yolu 10. km, Kütahya, Turkey. 


\section{The Alevî Perception in Sofca}

Even though the villagers respect and pay attention to Pîr Ahmed Efendi, the researcher determined that no talips were related to his ocak in the village. Those talips who lived the village were related to two other ocaks, those of Kocu Baba and Seyyid Kemal. During the interviews, it became clear that they have the traditional god ideal of Alevîsm that Allah is the only existence in the universe based on, as they declare, the Allah-Muhammed-Ali perception.

On the other hand, Prophet Muhammed (PBUH) was understood in terms of the "hakikati Muhammedî" concept, recalled and mostly equated with Ali in the sources of cultural Alevîsm. This declaration is symbolized as Muhammed-Ali. Talips from Sofca, Kutahya and Eskisehir answered positively and without hesitation when asked about Allah's existence and oneness as regards the Allah-Muhammed-Ali concept. The dominant views are that Prophet Muhammed (PBUH) is the Prophet of Allah and that there will be no other prophet after him; that he and Ali are two different personalities made from the same Nur (divine light); and that whereas Prophet Muhammed (PBUH) is a messenger, Ali is a saint in a state of sainthood and the lord of saints.

When asked about believing in angels, all of the dedes accept that Gabriel, Azrael, Michael and Israfil are archangels. Also, the Alevîs of Sofca inferred that the angels are made of divine light and that they neither eat nor drink. Residents (Sofcalılar) mostly embrace the issue of believing in angels with general sides and they have no interest in how they were created and have no mythological tales about them.

Although Sofca residents believe in the "Four Holy Books" and the "Holy Pages," they do not understand these in the same way that the Holy Quran does. Ali Garkın Dede of the Pîr Ahmed Ocak states that the Holy Quran could not been transferred from its own time to our own in an absolutely uncorrupted form. But Mustafa Dede and the Kemal Sultan Ocak talips hold that it cannot possibly be corrupt and deficient in any way. The Koculu Ocak talips have no overall united opinion, for although most of them hold the latter opinion, some adhere to the former one. Besides, while all of Sofca's residents say that they have a Kur'an in their houses, they also emphasize that they recite it during funerals and mawlids (birthday celebration of Prophet Mohammad). Most of them do not know how to recite the Holy Quran, but nevertheless want their children to learn how to do so.

As for the prophets, Mustafa Dede implies that those mentioned in the Holy Quran are said to sent by Allah and that they are messengers as well. Sofca's talips agree that the sending of prophets. The villagers also agree about Doomsday, the isthmian world (period between death and day of Judgement), heaven and hell, and the Day of Judgement, all of which are mentioned in the traditional Alevî sources. However, there are some disagreements between ocaks.

\section{Prayers, Etiquette and Practices}

\section{General Prayers}

In order to understand the perception of prayer in Sofca, one must know how its Alevî inhabitants perceive the ideals formulated as the "Five Requirements of Islam." Oktay 
Garkın Dede, who is a dede of the Pîr Ahmed Ocak, declares that there is no such Islamic requirements ideal in Alevîsm and posits the "Four Doors-Forty Levels" instead. Mustafa Dede, from the Seyyid Kemal Sultan Ocak, accepts the requirements of İslam and adds cleaning from junub (ritual impurity). It seems that this disagreement in viewpoint between the ocaks naturally resulted in different beliefs and practices.

As a result of observations and interviews conducted in Sofca, one can say that its residents generally do not come to the camii (mosque) to pray at the appropriate times and that only very rarely do even one or two people gather for the prayer. In terms of the Cuma (Friday) prayer, this number rises to seven or ten. Those talips who are related to the Seyyid Kemal Sultan Ocak care about the prayers, which reflects their dede's perception. However, the Koculu Ocak talips seem to be better practitioners in this regard.

Mustafa Dede says that performing the ritual ablution before praying is a duty and that the cleaning of every limb has a meaning. Moreover, talips have to receive a tarikat (mystic school) ablution once a year. Moreover, they go to the djem (cem) only after performing the appropriate ablution. Mustafa Dede's views are similar to those of Oktay Garkın Dede, who also asserts that ablution is a duty. In addition, Mustafa Dede, referencing the Holy Quran, says that performing the full ablution is a religious duty. All of Sofca's Alevîs answered the question of "What is your stand on full ablution?" by asserting that "I have my full ablution when it is necessary."

The Sofca resident's practices related to fasting resemble the ideals in ocaks, as do Alevism's other religious exercises. The Seyyid Kemal Ocak's talips observe the ritual fasts during Ramazan and Muharrem, whereas only half of those who belong to the Koculu Ocak believe that fasting is required and try perform it for both months. Another group from Koculu infer that they fast only in Muharrem and Hizır. Even though there is no disagreement in Sofca about the obligation to fast, carelessness can be seen in practice.

The dede of the Seyyid Kemal Sultan Ocak stressed that Alevî sources do not contain enough information about zekât/zakat (offering) to assert that is must be given. However, it is mentioned that in the Pîr Ahmed Ocak there is no concept of giving one-fortieth of one's property as there is in Islam; instead, the purpose of zekat is cooperation and allocation. As a reflection of this ocak's ideal among Sofca residents, instead of collecting zekât they undertake cooperative activities such prominent activities as helping the poor, distributing sadaka/ charity (benevolence), and serving ashoura (Noah's pudding).

The hajj practices of vakfe (pausing) in Arafat or of circumambulating the Ka'bah do not exist in the Pîr Ahmed Ocak. However, those in the Seyyid Kemal Sultan Ocak understand the hajj properly (i.e., in line with "orthodox" Sunni Islam) and regard it as a religious duty. When Sofca's residents were asked "Where would you visit first if you have opportunity?" they first replied Makkah (the Ka'bah) and Madinah (Masjid al-Nabawi), for the talips have a strong desire to visit those places. After that, Kerbela and then Nevsehir (the Tomb of Hacı Bektas Veli) were the most common answers. Some Alevîs infered that they have performed the hajj.

\section{Etiquette: Ceremonies and Practices}

Alevism is a system that has been shaped along the lines of a mystical cult. Therefore, its adherents have combined mystical methods and practices with their pre-Islamic beliefs 
and rituals. As a result, some new methods and practices have appeared. One of the fundamental ones is the cem, around which a great deal of etiquette and practices have been shaped. For example, during this gathering the "Twelve Acts of Service" (on iki hizmet) and the method of recognition (görgü erkanı) have to be performed in order to identify the "real" Alevis. The purpose of this annual event is to make sure that they have kept their promises, practiced companionship (musahiplik erkanı) that means making a fellowship between married couples, and methods of "getting lower from fatherland" practice which is made to asking for deceded one's blessing, "decrepitude practice" (düşkünlük erkanı) in which punished talip fell down, are most important ones of those practices.

\section{Result and Offers}

Pîr Ahmed Efendi, who is respected by Sunnî and Alevî societies, is a personality around whom a "caliphate of mysticism" has grown. He received his initial education in the Karamanlı Cem Seyyah and then at Sumbul Sinan in Istanbul, where he received his caliphate and then started his duty of dawah by coming to Kalburcu village. His son Sheikh Besir and his grandson Sheikh Ahmet Halvetî, who are known as muftî dervis, also belong to the Halvetî tradition. Sunullâh-ı Gaybî is also considered an important representative of this particular tradition as well.

Although Pîr Ahmed Efendi son and his descendants come from the Halvetî tradition, he is respected by the Alevîs in Sofca and thereabouts. Annual activities are arranged, many foods are served, and semah exhibitions (whirling dervish ceremonies) are held in his name. People from Sofca, as well as those from such surrounding cities as Kutahya and Eskisehir, are related to the Seyyid Kemal Sultan Ocak of Koculu. Even though Sofca has a Pîr Ahmed Efendi Ocak, no talips live in the village; however, some of them live in New Sofca and the surrounding villages. Once a year in Sofca, the people try to arrange the djemevi (djem-cem house) djem ceremony and do their best, in terms of communication and transportation, to make sure that all of the ocak talips attend. A cem ceremony is also being organized for the National Pîr Ahmet Efendi Memorial and Cultural Festival. This ceremony has two parts: one for the public and one restricted to recognized Alevîs.

\section{Conclusion}

The conducted interviews revealed that almost all Sofca residents self-identify as Alevîs. In addition, certain information of dedes about whether Alevîsm is a sect or a tarikat could not be seen in the talips. While the dedes describe Alevism as a tarikat, Sofca residents display no homogenized form. What is being described are predominantly a tarikat and a belief system. Very few talips accept Alevism as a sect, perhaps because they do not have enough information and are receiving it only from their parents and dedes.

In terms of their perception of Ali, its seen in Sofca people that their conscious and beliefs are straight. According to them, Ali is one of Allah's vassals and has nothing to do with being godlike. They accept Islam's basic fundamental beliefs (i.e., believing in Allah, angels, books, prophets, the Day of Judgement, predestination and destiny); however, some of the villagers understand them in accord with their own mysticm and traditional customs. This 
is the same for the ritual prayers. Thus how they observe these rituals, namely, salaah, fast, and zekât, differ from the practices of mainstream Sunni and Shi'i Muslims. That's why a careless understanding about prayers is a problem.

They have maintained good communications with those who do not hold the same beliefs, attend each other's important days and making mawlid ceremony when its necessary. Besides, imams take an active part in some matters, such as naming children and reading mawlid. In the past any marriage that took place among people belonging to different groups was not recognized. But this appears to have changed, for various reasons, as such unions now seem to be pretty common. On the other hand, due to people living in different places, the development of technology and other reasons, the villagers are having a hard time in terms of keeping their customs, traditions and beliefs alive. The Alevî elders are aware of this situation and are trying to find ways to resolve it.

In order to analyze the period of Pîr Ahmed Efendi, about which there is not much information, we intend to research foundation registries in the hope that they will lead us to new information. Moreover, it will be useful to make another study of the Halvetîsm-Alevîsm relationship in order to determine why a person connected to Alevîsm was accepted as a source of Halvetism.

\section{Kaynakça / References}

Aşkar, M. (1999). Bir Türk Tarikatı Olarak Halvetiyye'nin Tarihi Gelişimi ve Halvetiyye Silsilesinin Tahlili, Ankara Üniversitesi İlahiyat Fakültesi Dergisi ( c. 39, sy. 1; s. 535-563). Ankara.

Atâî, N. î. (1269). Zeyl-i Şekâik (c. I). Matbaa-i Âmire.

Cura, U. (Ed.). (2012). Buyruk. Balıkesir: Altınpost Yayıncılık.

Bozkurt, F. (Hzl.). (2013). Buyruk: Imam Cafer-i Sadık Buyruğu (4. Baskı). İstanbul: Kapı Yayınları.

Çelebi, E. (1935). Seyahatnâme (c. IX). İstanbul.

Doğan, A. (2001). Kütahyalı Sunullah Gaybî Hayatı, Fikirleri, Eserleri. İstanbul.

el-Hulvî, M. C. (1993). Lemezât-ı Hulviyye ez-Leme'ât-ı Ulviyye (Büyük Velîlerin Tatıı Halleri) (M. S. Tayşi, Hzl.). İstanbul: IFAV.

Gaybî, S. I.-I. (854). Biatnâme (Akâidnâme, Biatnâme, Rûhu'I-Hakîka). Bursa İnebey Yazma Eser Kütüphanesi.

Kaplan, D. (2011a). Alevilikte Muhammed-Ali Tasavvuru: Bir Ten İki Baş ya da İki Ten İki Baş Sembolizminin Kültürel Temeli. (Ed.), Kültür Coğrafyamızda Hz. Muhammed Uluslararası Sempozyum Bildiriler Kitabı içinde (c. I-II, s. 147-159). Ankara: Diyanet İşleri Başkanlığı.

Kaplan, D. (2011b). Yazılı Kaynaklarına Göre Alevilik. Ankara: Türkiye Diyanet Vakfı yayınları.

Kemikli, B. (2000). Sun'ullah-ı Gaybî Hayatı-Eserleri-Şiirleri. Ankara: Akçağ Yayınları.

Kurnaz, M. T.-C. (1999). Kütahyalı Bir Gönül Eri Çavdaroğlu Müftî Derviş. Ankara: Akçağ Yayınları.

Ocak, A. Y. (1996). Babaîler İsyanı Aleviliğin Tarihsel Altyapısı. İstanbul: Dergah Yayınları.

Süreyya, M. (1996). Sicill-i Osmânî (N. Akbayar, Hzl.). İstanbul.

Uzunçarşılı, İ. H. (1932). Kütahya Şehri. İstanbul

Üçer, C. (2010). Geleneksel Alevilikte İbadet Hayatı, Bazı Âdâb ve Erkân In H. İ. Bulut (Ed.), Anadolu'da Aleviliğin Dünü ve Bugünü (s. 457-510). Sakarya.

Üzüm, İ. (2013). Tarihsel ve Kültürel Boyutlarıyla Alevilik (3 ed.). İstanbul: ISAM Yayınları.

Yavuz, Y. Ş. (2001). Kader. DiA içinde (c. XXI, s. 58-63). İstanbul: Türkiye Diyanet Vakfı.

Yılmaz, A. Y.-H. (2002). Kargın Ocaklı Boyu Ille Illgili Yeni Belgeler. Hacı Bektaş Veli Araştırma Dergisi, (21), 13-87.

Yılmaz, H. (2013). Halvetilik ve Anadolu Aleviliği Ilişkisi Çerçevesinde Pir Ahmet Efendi Ahfadına Genel Bir Bakış, NEÜ Sosyal Bilimler Enstitüsü Dergisi (sy. 2, s. 121-130). 